\title{
Einkenni og áskoranir tónlistarklasa á Íslandi
}

\author{
Freyja Gunnlaugsdóttir og Runólfur Smári Steinpórsson ${ }^{1}$
}

\begin{abstract}
Ágrip
Pessi grein fjallar um próun tónlistarlífs á Íslandi á undanförnum árum. Margir íslenskir tónlistarmenn hafa átt velgengi að fagna og skapað sér nafn á alpjóðlegum markaði. Stjórnvöld hafa stutt við próunina á ýmsan hátt og pau hafa mikil áhrif á tónlistarlífið. Umsvifin í greininni benda til að próunin undanfarin ár hafi ýtt undir myndun klasa í tónlist á Íslandi. Markmiðið með pessari grein er að rannsaka próun tónlistarlífs á Íslandi út frá kenningum um klasa og samkeppnishæfni. Einnig er próunin á Íslandi borin saman við pekkta tónlistarklasa erlendis. Byggt er á raundæmisrannsókn par sem spurt er að hvaða marki megi líta á tónlist á Íslandi sem klasa og ef svo er á hvaða stigi klasapróunar íslenskur tónlistarklasi kunni að vera. Einnig er spurt um hvaða áskoranir tónlistarklasinn kunni að standa frammi fyrir. Niðurstöður gefa til kynna skýrar vísbendingar um tónlistarklasa á Íslandi og að klasinn sé að færast af mótunarstigi yfir á próunarstig. Í niðurstöðum felst hagnýtt gildi pví varpað er ljósi á atriði og aðstæður sem geta ýtt undir frekari uppbyggingu á sterkum tónlistarklasa á Íslandi. Samhliða er tónlistarklasinn dæmi um klasa í litlu fámennu landi og niðurstöðurnar framlag til pekkingar á klasa í slíkum aðstæðum.
\end{abstract}

\begin{abstract}
Music as part of creative industries in Iceland has been on a positive growth path. Many musicians from Iceland have been succesful in establishing their name and brand internationally. The government has played a critical role in the growth of the music field. There are manifestations that provide support for the existence of a music cluster in Iceland. The purpose of this article is to study the music field from a cluster perspective and reflect on the development with reference to well known music clusters abroad. On the basis of a case study method and cluster assessment tools it is analysed to what extent it is possible to confirm the existence of a music cluster in Iceland. There are clear indications of a music cluster and it is concluded that the music cluster can be described as a potential cluster. The context of the cluster can also be seen as positive for further development but there are many challenges identified.
\end{abstract}

JEL flokkun: M1, M2

Lykilorð: Tónlist; klasar; klasapróun: samkeppnishæfni

Keywords: Music; cluster; cluster development; competitiveness

\section{The characteristic of a music cluster in Iceland}

1 Freyja Gunnlaugsdóttir, tónlistarmaður og aðstoðarskólameistari í Menntaskóla í tónlist. Netfang: freyja@ menton.is. Runólfur Smári Steinpórsson, prófessor við Viðskiptafræðideild Háskóla Íslands. Netfang: rsmari@hi.is.

This work is licensed under a Creative Commons Attribution 4.0 License.

(C) Tímarit um viðskipti og efnahagsmál

www.efnahagsmal.is 


\section{Inngangur}

Á síðustu árum hefur íslenskt tónlistarfólk vakið eftirtekt í alpjóðlegu tónlistarlífi. Íslensk tónlist hefur fengið góða umfjöllun víða um lönd og margir íslenskir tónlistarmenn ná eyrum manna um allan heim. Pessi próun hefur vakið athygli á Íslandi og gefið jákvæða mynd af landi og pjóð (Gylfi Dalmann Aðalsteinsson og Helga Björg Ragnarsdóttir, 2003; Kristján Már Gunnarsson, 2016; Forsætisráðuneytið, 2008).

Tónlistarlíf byggist að hluta til á samvinnu ólíkra aðila. Tónlistarmenn og samstarfsfólk vinnur að sköpun tónlistar, tónlistarflutningi og dreifingu tónlistar. Afurðin, tónlistin sjálf, hefur bæði menningarlegt og efnahagslegt gildi fyrir einstaklinga, fyrirtæki og stofnanir innan tónlistargeirans sem og mikla pýðingu fyrir pjóðina í heild (Caves, 2000; Throsby, 2003; Towse, 2010; Ágúst Einarsson, 2013). Viðfangsefni pessarar greinar er að skoða tónlistarlífið á Íslandi með pað fyrir augum að fá úr pví skorið hvort hér á landi séu skilyrði uppfyllt fyrir tilvist tónlistarklasa (e. music cluster) og í framhaldinu ræða stöðu klasans og áskoranir hans. Greininni er ætlað að skila hagnýtu framlagi til tónlistargeirans og framlagi til klasafræðanna, m.a. varðandi klasa í litlu fámennu landi eins og Íslandi.

prátt fyrir framfarir á liðnum árum liggur fyrir að tónlistargeirinn á Íslandi stendur frammi fyrir erfiðum áskorunum sem nauðsynlegt er að takast á við svo próunin haldi áfram í rétta átt. Ein af peim áskorunum er hvernig megi styðja við og byggja upp enn betra menntakerfi í tónlist á Íslandi, sem svo skili tónlistarlífinu vel menntuðum og hæfum tónlistarmönnum á næstu árum (Freyja Gunnlaugsdóttir, 2015). Pessar áskoranir virðast um margt líkar peim sem pekkjast við próun klasa á sviði tónlistar erlendis (Beyers, Bonds, Wenzl og Sommers, 2004; Bernard, Chaturveti, Hill, Maddox og Schrimpf, 2012). Erlendar rannsóknir hafa pannig gefið tilefni til að beita peirri nálgun að skoða tónlist á Íslandi út frá sjónarhorni klasa (e. cluster) og samkeppnishæfni (e. competitiveness). Leiðarljós höfunda við rannsóknina er að með klasanálgun og hagnýtingu klasafræða megi varpa ljósi á stöðu íslenskrar tónlistar og hvernig megi ýta undir frekari próun klasa og vöxt í tónlist á Íslandi.

Í pessari grein eru pessi viðfangsefni tónlistargeirans tekin til skoðunar út frá klasanálgun. Rannsóknarspurningarnar eru eftirfarandi: 1) Hvernig má skoða tónlist á Íslandi sem klasa? 2) Hvernig hefur klasinn próast með hliðsjón af próunarskeiðum klasa? 3) Hver eru brýnustu viðfangsefnin svo klasinn nái að dafna og skila ávinningi?

Greinin miðar öll að pví að svara pessum spurningum og í niðurstöðum er sett fram klasakort (e. cluster map) af íslenska tónlistarklasanum til að fá mynd af klasanum og lýsa stöðu hans í dag. Lagt er mat á stöðu hans í próunarferli klasa (e. cluster development cycle). Einnig er nánar fjallað um hvaða áskoranir klasinn stendur frammi fyrir og hvað geti verið til ráđa í frekari próun hans. Jafnframt er fjallað um framlag rannsóknarinnar til pekkingar á klösum og klasastarfi.

Í pessari grein er stuðst við kenningar Michaels E. Porter (1990, 1998, 2000, 2003, 2008) um klasa og einnig líkan Michaels Enright (2003) á próunarskeiðum klasa og greiningarvinnan tekur einnig mið af peim. Fyrst er gerð grein fyrir nálgun Porters og fjallað nánar um hana í samhengi við aðrar klasakenningar, ekki síst í tengslum við tónlistarklasa.

\section{Klasafræði og klasar á sviði tónlistar}

Til að varpa ljósi á íslenska tónlistarklasann og stöðu hans í próunarferli klasa er nauðsynlegt að skoða próun hans í ljósi klasakenninga. Fræðin um klasa eiga sér yfir aldargamla sögu og til eru yfirlitsgreinar sem gefa mynd af próun kenninganna og fjölbreytninni pegar kemur að grundvallarskilgreiningum (Cruz og Teixera, 2010; Lazzeretti o.fl., 2014). Próun klasakenninga hefur verið dregin saman í ólíka skóla (Deutz og Gibbs, 2008) sem leggja áherslu á ólíka hluti, svo sem iðnaðarhverfi Marshalls, ítalska skólann, sveigjanlega sérhæfingu, samkeppnishæfni og klasa, svæðisbundna próun og pekkingu og tengslanet (Guðjón Örn Sigurðsson og Runólfur Smári Steinpórsson, 2014a). Einn af pessum skólum í klasafræðum er nálgun Michaels E. Porters. 


\subsection{Klasanálgun Porters}

Að mörgu er að hyggja pegar kemur að skilgreiningum á klösum. Martin og Sunley (2003) benda á að sjálft klasahugtakið megi rekja til Michaels Porter en telja skilgreiningu hans pó frekar óljósa. Í kenningum Porters er litið á klasa sem pyrpingu fyrirtækja og stofnana sem tengjast tiltekinni starfsemi á tilgreindu landfræðilega afmörkuðu svæði par sem bæði samvirkni og samkeppni gætir á milli aðila (Porter, 1998, 2008). Innan klasa er pannig að finna margháttað samspil á milli fyrirtækja og stofnana, bæði samkeppni og samstarf, sem jafnan skilar sér í almennt bættum hag viðkomandi starfsgreinar (Ketels og Sölvell, 2006). Samspil innan klasa felur í sér að fyrirtæki og stofnanir geta bætt stöðu sína og laðað til sín hæft starfsfólk um leið og klasasamstarfið ýtir undir miðlun pekkingar, tæknikunnáttu og annarra hagnýtra upplýsinga (Lindqvist, Ketels og Sölvell, 2012). Virkur klasi stuðlar að verðmætasköpun og samkeppnishæfni fyrirtækjanna og hefur einnig jákvæð áhrif á stofnanirnar sem starfa innan klasans (Ketels, 2013). Petta allt stuðlar að eflingu og hagvexti á viðkomandi svæði (Porter, 1998, 2003; Delgado o.fl., 2014).

Klasahugtakið nær yfir fleiri aðila á tilteknu svæði en hugtakið atvinnugrein. Atvinnugrein er jafnan skilgreind út frá staðlaðri atvinnugreinaflokkun sem miðast við aðalafurðina sem framleidd er í viðkomandi atvinnugrein (Stiles, 1992). Fyrirtækin í atvinnugreininni sem telst vera aðalstarfsemi klasa, mynda kjarna klasans. Hugtakið klasi varpar ljósi á að oft eru pað fyrirtæki utan aðalatvinnugreinarinnar sem veita mikilvæga pjónustu sem ýtir ekki síður undir verðmætasköpunina í klasanum (Sölvell, Lindqvist og Ketels, 2003; Ffowcs-Williams, 2012; Lindqvist o.fl., 2012). Innan tónlistarklasa má nefna ólíka aðila sem koma að framleiðslu tónlistar á geisladiski. Pótt sköpun tónlistarinnar sé í kjarna klasans pá eru allir sem koma að framleiðslunni nauðsynlegir pátttakendur í henni. Petta eru til dæmis auk tónlistarmanna, grafískir hönnuðir, umboðsskrifsstofa, prentsmiðja, upptökuver og dreifingaraðilar. Öll pessi fyrirtæki og einstaklingar eru hluti af sama klasa pegar peir vinna saman að t.d. framleiðslu eins geisladisks (Beyers o.fl., 2004).

Klasar geta ráðið miklu um samkeppnishæfni pjóða í alpjóðlegu samhengi (Porter, 1990), ekki síst ef peir hafa náð að próast hvað varðar stöðu og umsvif pannig að viðkomandi klasa megi lýsa sem virkum (e. working cluster) (Enright, 2003). Öflug starfsemi á heimamarkaði, par sem próast hefur bæði pekking og færni sem stuðlar að samkeppni og samvirkni á milli fyrirtækja og stofnana, verður til pess að bæði fyrirtæki og klasar standa sterkari að vígi í alpjóðlegu umhverfi (Porter, 1990, 2003). Virkur klasi eykur nýsköpun, stuðlar að aukinni framleiðni, hvetur til góðra viðskiptahátta og ýtir undir traust (Porter, 1998, 2008; Delgado o.fl., 2014). Virkur klasi er til marks um gróskumikla starfsemi á tilteknum svæði sem hefur aðdráttarafl og laðar til sín fleiri verkefni og viðskipti, ekki síst erlendis frá (Ketels og Memedovic, 2008). Í virkum klasa eru margir og mismunandi aðilar pátttakendur og innan hans er unnið að verkefnum og samræmingu sem oft eru skipulögð innan svokallaðra klasaframtaka (e. cluster initiatives) (Ketels og Memedovic, 2008; Guðjón Örn Sigurðsson og Runólfur Smári Steinpórsson, 2014b; Runólfur Smári Steinpórsson, 2016b).

Hugtakið klasi varpar einkum ljósi á prennt: a) tiltekna staðsetningu par sem fyrirtæki og stofnanir tengdar tiltekinni starfsemi hafa safnast saman, b) virka efnahagsleg starfsemi sem leiðir til verulegrar verðmætasköpunar á svæðinu og dregur pannig fram sérstöðu pess á alpjóðavísu, og c) viðskiptaumhverfi klasans markast af framangreindu samspili og pegar vel gengur verður til jákvæður spírall vegna peirra ytri áhrifa sem efla klasann (Ketels og Memedovic, 2008). Par sem klasi er virkur og öflugur njóta fyrirtæki, stofnanir og svæði sem eiga í hlut aukinnar hagsældar vegna samsöfnunar, samtengingar og samvirkni sín á milli (Wolman og Hincapie, 2015).

Klasa má skoða sem náttúrulegt fyrirbæri (Ketels og Memedovic, 2008) með tengsl við sögu og hefðir á peim svæðum sem pá er að finna (Berg o.fl., 2014). Peir eru líka mismunandi (Markusen, 1996; Ketels, 2003) og pess vegna er mikilvægt að átta sig á pví hvers konar virkni og starfsemi stuðlar að pví að peir nái að próast (Porter, 2003). Margt hefur 
áhrif á pessa próun og má par nefna samspil á milli peirra aðila sem starfa innan klasans (Best, 2001; Lindqvist o.fl., 2012), pátt háskóla (Wolfe, 2005; Smith, 2007) og klasamiðaða nálgun stjórnvalda (Ketels, 2009).

Meginmarkmiðið með pví að efla klasa er að stuðla að hagsæld og treysta samkeppnishæfni viðkomandi starfsemi á ákveðnu landsvæði. Petta er mögulegt með með pví að ýta undir virkni klasans, eins og fyrr segir, t.d. með klasaframtaki (e. cluster initiative) sem meðal annars getur miðað að pví að koma á góðri tengingu milli atvinnulífs, háskóla og rannsóknarstofnana en slíkt samstarf stuðlar að nýsköpun og frampróun innan atvinnugreinarinnar í heild (Sölvell o.fl., 2003). Með nánu samstarfi tekst fyrirtækjum og stofnunum að samnýta auðlindir og pekkingu og ná pannig samlegðaráhrifum sem hafa jákvæð áhrif á starfsemina (Rosenfeld, 1997). Próun klasa byggist að mestu leyti á samvinnu fyrirtækja og stofnana í viðkomandi atvinnugreinum og tengdum greinum en einnig á menningarlegum og félagslegum grunni (Guðjón Örn Sigurðsson og Runólfur Smári Steinpórsson, 2014a). Jafnvel pó að fyrirtæki eigi í samkeppni getur samstarf af pessu tagi aukið verðmætasköpun og eflt samkeppnishæfni fyrirtækja innan greinarinnar (Porter, 1998; Ketels, 2009).

Ekki er hvað síst mikilvægt að ýta undir nýsköpun og stuðla pannig að verðmætasköpun og endurnýjun innan greinarinnar. Verðmæti geta jafnframt falist í orðspori, pekkingu, hæfni starfsmanna, tæknigetu og menningu stofnana (Austin, 2000). Stofnanir og fyrirtæki geta byggt upp sameiginlegan pekkingargrunn með pví að skiptast á sérhæfðri pekkingu sem nýtist peim sem starfa innan klasans á margvíslegan hátt. Par skiptir gott upplýsingaflæði og góð samskipti milli peirra sem starfa innan greinarinnar miklu máli (Sölvell o.fl., 2003; Lindqvist o.fl., 2012).

\subsection{Klasar í listgreinum og tónlist}

Í listgreinum er algengt að listsköpun byggist á samstarfi ólíkra aðila innan sömu greinar. Pví er ekki óalgengt að klasar próist innan listgreina og margir hafa haldið pví fram að klasasamstarf sé að mörgu leyti drifkraftur peirra (Power og Jansson, 2006; Vang, 2007). Víða eru listklasar sjálfsprottnir og byggjast að miklu leyti upp á persónulegum tengslum ólíkra aðila sem starfa innan sama klasa (Chapain, Cook, De Propris, McNeill og MateosGarcia, 2010). Раð er raunar eðli klasa að vera sjálfsprottnir (Ketels, 2003). Peir klasar par sem jákvæð ytri áhrif eru virkust og verðmætasköpun einna mest tengjast jafnan útflutningi og alpjóðaviðskiptum frekar en staðbundnum viðskiptum (Porter, 2003). Listklasar og tónlistarklasar eru alpjóðlegir í eðli sínu og byggjast á skapandi fólki í skapandi störfum sem líka er lykill að aukinni verðmætasköpun (Florida, 2002). Einnig hefur verið bent á að með pví að tvinna saman nálgun Porters, sem varpar ljósi á virka og árangursríka klasa á tilteknum svæðum, og kenningu Florida, um pýðingu pess að störf miði að sköpun og að fólk sé skapandi, megi ná enn betur utan um pað hvaða klasar með alpjóðlega skírskotun séu að skila framúrskarandi verðmætasköpun og jafnframt hvað pað er sem helst einkenni aðstæður og skilyrði slíkra klasa (Martin o.fl., 2015).

Klasar próast á mismunandi hátt og hlutverk stjórnvalda getur verið frá pví að vera mjög lítið yfir раð að vera mikið (Fromhold-Eisebith og Eisebith, 2005). Á fyrstu stigum klasapróunar, sem tekur jafnan langan tíma, er sjaldgæft að einhver einn aðili hafi beina aðkomu að klasapróuninni, p.e. peirri samsöfnun fyrirtækja og stofnana sem er að myndast á tilteknum stað og pví samspili og samvirkni sem próast á milli aðila. Aðstæður eru pví pannig að pað er ekki verið að ýta með neinum sérstökum hætti undir tækifæri sem klasasamstarfið býður upp á (Porter, 2000). Рað er eðli klasa að byggja á gömlum grunni og mótast smám saman yfir lengri tíma (Ketels, 2003). Ef stjórnvöld hafa vilja til að efla klasasamstarf getur verið gagnlegt að styrkja pá klasa sem eru til staðar og ýta undir frekari próun innan peirra (Chapain, Cook, De Propris o.fl., 2010). Eftir að klasi hefur verið kortlagður gefst tækifæri til að huga að klasaeflandi aðgerðum, par með talið að hefja stefnumótun og skoða hvernig megi efla klasann og bæta vaxtarskilyrði hans (Sölvell o.fl., 
2003; Lindqvist o.fl., 2012; Sölvell og Williams, 2013). Öflugur og virkur klasi getur skilað miklum ávinningi til atvinnugreinarinnar og samfélagsins í heild (Chapain o.fl., 2010).

Innan listgreina byggjast klasar á peim listamönnum sem starfa innan greinarinnar og vinna að listsköpum, peirri frampróun sem hefur orðið innan hennar og nýsköpun í listum og menningu. Pannig verður til vettvangur innan klasa par sem hæfileikafólk mætist, nýjar hugmyndir koma fram og fólk veitir hvert öðru hvatningu og innblástur (Chapain o.fl., 2010; Boix, Lazzaretti, Hervás og De Miguel, 2011). Klasasamstarf í listgreinum stuðlar að tjáningargleði, listrænni örvun og ætti að auka fjölbreytileika innan greinarinnar (Chapain o.fl., 2010). Klasi er jafnframt vettvangur fyrir tengslanet listamanna og sérfræðinga sem hafa mikil áhrif á menningu pess landsvæðis par sem viðkomandi klasa er að finna. Einstaklingar leika oft stærra hlutverk innan listklasa en annarra klasa og jafnframt gegna ýmsar stofnanir sem ekki eru reknar af hagnaðarsjónarmiðum oft mikilvægu hlutverki (Chapain o.fl., 2010; Boix, Lazzaretti o.fl., 2011). Áhugaverð nýsköpun innan listklasa á sér stað í grasrótinni og pví er lykilatriði að hlúa vel að henni og sjá til pess að ungir og hæfileikaríkir listamenn fái tækifæri til pess að vinna að list sinni og koma henni á framfæri (Chapain o.fl., 2010; Jansson og Power, 2010). Listgreinar hafa vaxið ört á síðustu árum og margir halda pví fram að skapandi greinar hafi átt stóran hlut að máli í efnahagsbata margra landa eftir efnahagsprengingar síðustu ára (Chapain o.fl., 2010; Power og Janson, 2006; Vang, 2007).

Í listklasa deila fyrirtæki og stofnanir sérhæfðri pekkingu og hæfileikum sem nýtist peim sem starfa innan hans (Ágúst Einarsson, 2012). Stofnanir og fyrirtæki sækja pekkingu og stuðning frá peim sem standa að sambærilegri starfsemi og ólíkir aðilar ná pannig að samnýta pekkingu og pá hæfileika sem er að finna í mannauðnum innan klasans. Petta er oft kallað pekkingarflakk eða jákvæð ytri áhrif (e. spillover effect) (Marshall, 1920). Aðgengi að upplýsingum innan ákveðinna listgreina er á hinn bóginn oft takmarkað og pví getur verið erfitt að safna nægilegum gögnum til pess að öðlast yfirsýn yfir gróskuna í listgreinum á ákveðnu landsvæði (Boix o.fl., 2011; Ágúst Einarsson, 2012). Klasar í listgreinum eru pó yfirleitt fyrir hendi í péttbýli, ekki síst í miðbæjum stórborga, par sem finna má fjölda menningarstofnana og listaháskóla sem tengjast oft innbyrðis. Klasarnir eru oft og tíðum afmarkaðir á litlu svæði og nálægð og samvinna er mikil innan peirra (Power og Jansson, 2006; Lazzeretti, 2008; Heur, 2008).

Sem dæmi um tónlistarklasa innan stórborgar er tónlistarklasi Berlínarborgar, en par er að finna á mjög litlu svæði í borginni tónlistarháskóla, tvö óperuhús, stóran tónleikasal og ótal fleiri stofnanir sem tengjast tónlist (Berlin music commission, e.d). Pessar stofnanir tengjast á margan hátt, styrkja hver aðra og samnýta ýmsa pætti, bæði í listrænum og rekstrarlegum skilningi. Svipuð dæmi má finna víða í stórborgum Vesturlanda. Árið 2011 gerðu Boix, Lazzaretti, Hervás og De Miguel víðtæka rannsókn sem fólst í pví að kortleggja klasa innan listgreina og annarra skapandi greina í Evrópu. Kortlagðir voru 1.784 listatengdir klasar í Evrópu og niðurstöður sýndu að stærstu listklasana væri að finna í hjarta stórborganna (Boix o.fl., 2011). Rannsakendur ályktuðu af pessu að stóru klasarnir væru umkringdir fleiri minni klösum innan sömu greina. Rannsóknin leiddi einnig í ljós að stærstu klasana væri að finna í London og París. Klasar sem voru greindir á sama landsvæði tengdust oft sterkum böndum og samvinna milli peirra var mikil (Boix o.fl., 2011). Áður hafði Lazzeretti (2008) fjallað um listklasa og niðurstaða hans var að samvinna sé nánari og sampjöppun meiri í listgreinum en í öðrum atvinnugreinum. Margir prengri klasar innan sömu greinar geta prifist í sömu borg eða á sama svæði. Stórar borgir einkennast oft af fjölbreytni í listum og fjölmenningarlegu umhverfi í listum og menningu. Tónlistarlíf stórborga er enn fremur yfirleitt hægt að greina í margar ólíkar tónlistarstefnur og greinar sem starfa hlið við hlið (Freemann, 2010).

Árið 2004 var gerð rannsókn við Háskólann í Washington í samvinnu við borgaryfirvöld Seattle par sem tónlistarklasinn í Seattle var kortlagður og viðtöl tekin við listamenn og stjórnendur lykilstofnana og fyrirtækja á sviði tónlistar í borginni (Beyers, Bonds, Wenzl 
og Sommers, 2004). Rannsóknin leiddi í ljós að stofnanir og fyrirtæki á sviði tónlistar höfðu gegnt lykilhlutverki í efnahagslegri uppbyggingu borgarinnar á árunum ádur en rannsóknin var gerð. Hið áhugaverða og einstaka tónlistarlíf borgarinnar var metið sem ein af verðmætustu auðlindum sem hún hafði yfir að ráða. Áheyrendur komu víða að til pess að njóta pess fjölbreytta og áhugaverða tónlistarlífs sem er í Seattle. Einnig höfðu ýmis fyrirtæki innan tónlistariðnaðarins og tónlistarmenn flutt starfsemi sína til borgarinnar vegna aðstöðunnar sem par er til staðar. Fjölmörg upptökuver er að finna í borginni og mikill fjöldi tónlistarmanna kemur pangað til pess að hljóðrita verk sín. Niðurstaða rannsóknarinnar var að Seattle stæði sterkum fótum í tónlistariðnaðinum á alpjóðlegan mælikvarða og væri samkeppnishæf í alpjóðlegu tónlistarlífi. Pær aðstæður sem gerðu petta mögulegt voru ekki síst öflugar menntastofnanir, fyrsta flokks upptökuver, tónleikasalir og gott orðspor sem borgin hefur öðlast í tónlist pegar til lengri tíma er litið. Í skýrslunni er sérstaklega fjallað um að í Seattle sé gott aðgengi að tónlistarmenntun og að tónlistarskólakerfið sé öflugt. Seattle reyndist líka hafa markvisst byggt upp gott menntakerfi og veitir stuðning til tónlistarmenntunar (Beyers o.fl., 2004).

Priðja dæmið um rannsókn par sem fjallað er um tónlistarklasa er frá höfuðvígi kántrítónlistar í Bandaríkjunum, Nashville í Tennessee-fylki (Bernard, Chaturveti o.fl., 2012) Rannsóknin sýndi fram á að tónlistariðnaðurinn í Nashville var eina atvinnugreinin par á bæ sem efnahagskreppan sem hófst árið 2008 hafði ekki haft nein áhrif á. Borgaryfirvöld höfðu á markvissan hátt byggt upp sterkan tónlistarklasa, fjárfest í menntakerfinu og markaðssett tónlistarlíf borgarinnar. Tónlist hefur alltaf gegnt mikilvægu hlutverki í daglegu lífi Nashville-búa og er stór hluti af sjálfsmynd borgarinnar. Borgaryfirvöld nýttu sér orðsporið sem fór af tónlistarlífi Nashville til pess að byggja par upp sterkan tónlistarklasa (Bernard o.fl., 2012). Borgin skapaði pannig góðar aðstæður fyrir fyrirtæki og stofnanir innan tónlistariðnaðarins svo pau gætu vaxið og dafnað. Borgin var markvisst markaðssett sem góður staður fyrir tónlistarmenn til að hljóðrita tónlist sína og pekkt er að upptökuver borgarinnar bjóða lægra verð en sambærileg upptökuver í t.d. Los Angeles (Bernard o.fl., 2012; Harper, Cotton og Benefield, 2013). Pess vegna hafa á undanförnum árum mörg fyrirtæki í tónlistariðnaðinum flutt starfsemi sína til Nashville par sem aðstæður eru góðar (Bernard o.fl., 2012; Harper o.fl., 2013). Jafnframt er boðið upp á fjölda tónlistarhátíða par sem byggt er á fornri frægð Nashville og peirri tónlistarhefð sem er upprunnin á pessu svæði (Bernard o.fl., 2012; Harper o.fl., 2013). Fjöldi manns sækir borgina heim á hverju ári til pessa að njóta pess að hlusta á fjölbreytta kántrítónlist á heimaslóðum hennar (Bernard o.fl., 2012). Borgaryfirvöld í Nashville tóku einnig pá ákvörðun að leggja sérstaka áherslu á góða tónlistarmenntun og að byggja upp gott tónlistarskólakerfi í borginni. Staða tónlistarklasans í Nashville er líka til umfjöllunar í rannsókn Harper og meðhöfunda en par kemur fram að fjöldi peirra sem vinna í tónlistarklasanum í Nashville er nálægt prisvar sinnum meiri en á öðrum stöðum í Bandaríkjunum (Harper o.fl., 2013).

Í ofangreindum rannsóknum á tónlistarklösum er bent á borgir sem gerðu sér grein fyrir sérstöðu sinni innan tónlistariðnaðarins og notuðu hana til pess að byggja upp öflugt tónlistarlíf. Í pessum rannsóknum er fjallað um mikilvægi pess að skapa aðstæður par sem listamenn, stofnanir og fyrirtæki innan tónlistariðnaðarins njóta góðra skilyrða til pess að blómstra.

\section{Rannsóknaraðferð}

Í pessari rannsókn á pví hvort finna megi vísi að tónlistarklasa á Íslandi er fyrst og fremst stuðst við aðferðafræði raundæmisrannsókna (Eisenhardt, 1989; Yin, 2003). Sú nálgun hentar vel pegar rýnt er í eitt eða fá raundæmi. Raundæmisrannsókn (e. case study) byggist á margs konar raungögnum, ýmist fyrirliggjandi gögnum eða frumgögnum, um samtímafyrirbæri og út frá peim er pað skoðað í sínu eigin samhengi (Yin, 2003).

Rannsóknir á klösum eru margvíslegar og ná pær bæði á breiddina og dýptina. Sem dæmi um rannsóknir á breiddina má nefna kortlagningu klasa í Bandaríkjunum (Cluster 
Mapping, mapping a nation of regional clusters, e.d.) og í Evrópu (Clusters at your fingertips, e.d.). Í peim byggist kortlagningin að miklu leyti á fyrirliggjandi gögnum um atriði eins og fyrirtæki og stofnanir, staðsetningu peirra, atvinnupátttöku, laun og útflutning. Unnið er úr pessum gögnum á tölfræðilegan hátt. Raundæmisrannsóknir eru einnig og ekki síður nýttar við greiningu á stökum klösum til að afla dýpri upplýsinga en tekst að ná fram með kortlagningu á breiddina (Ketels og Sölvell, 2006).

Af pessum ástæðum er aðferðafræði raundæmisrannsókna talin falla best að peirri rannsókn sem hér er framkvæmd. Fyrir pví eru nokkrar ástæður. Í fyrsta lagi er rannsóknin framhald á fyrirliggjandi raundæmisrannsókn par sem byggt er á fyrirliggjandi gögnum (Freyja Gunnlaugsdóttir, 2015). Í öðru lagi er pessi rannsókn hluti af stærra rannsóknarverkefni par sem markmiðið er að fá innsýn og yfirsýn yfir mörg raundæmi um klasa á Íslandi (Runólfur Smári Steinpórsson, 2016a). Í priðja lagi eru aðferðafræðileg rök fyrir pessari nálgun pví ætlunin er að ná utan um tiltekið fyrirbæri í raunveruleikanum sem raundæmi (e. case) með fjölbreyttum gagnaöflunaraðferðum og par á raundæmisrannsókn vel við (Robson, 1993; Yin, 2003).

Við gagnaöflunina um tilvist og stöðu tónlistarklasa á Íslandi hefur verið tekið mið af viðmiðum Ketels og Sölvells (2006) við klasagreiningu. Gagnasöfnun fór fram á tímabilinu 2014-2016 og áherslan var á að safna fjölbreyttum gögnum úr ólíkum áttum til að átta sig sem best á pví sem varpar ljósi á mögulegan tónlistarklasa og forsendum fyrir hann. Frjáls aðgangur fékkst að öllum gögnum varðandi tónlistariðnaðinn á íslandi hjá Félagi íslenskra hljómlistarmanna. Upplýsingar um lög og reglugerðir voru sóttar af heimasíðu Alpingis og ýmsar gagnlegar upplýsingar á vef ráđuneyta og Reykjavíkurborgar. Jafnframt var stuðst við skýrslur, blaðagreinar, skriflegar frásagnir, bækur, greinar og annað útgefið efni um tónlistarlífið. Gerð er sérstök grein fyrir pessum gögnum og greiningu á peim í kafla um forsendur fyrir tónlistarklasa á Íslandi.

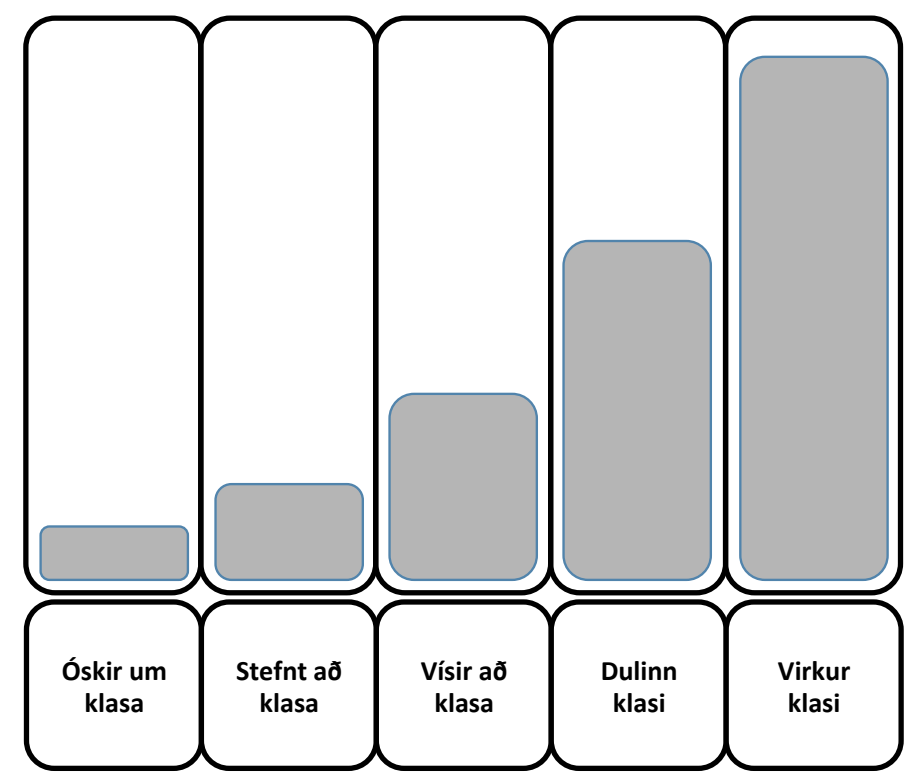

Mynd 1. Fimm skeið í próun klasa (byggð á Enright, 2003)

Við frekari úrvinnslu gagnanna og framsetningu á niðurstöðum um tónlistarklasann er í fyrsta lagi stuðst við klasakort sem verkfæri (Porter, 1990, 1998; Austrian, 2000). Klasakort er grafísk framsetning á peim klasa sem er til umfjöllunar og aðferðinni er ætlað að draga fram pá aðila sem telja má til klasans og hafa með höndum verkefni sem hafa sérstaka pýðingu fyrir klasann og virkni hans (Porter, 1990, Runólfur Smári Steinpórsson, 2016a).

Í öðru lagi er gerð greining á gögnunum til að meta á hvaða skeiði í próun klasa megi telja að tónlistarklasi á Íslandi sé. Hér er stuðst við nálgun Michaels Enright (2003) sem 
skiptir próunarskeiðum klasa í fimm skeið. Pessi skeið eru a) ósk um klasa (e. wishful thinking cluster), b) stefnt að klasa (e. policy-driven cluster), c) vísir að klasa (e. potential cluster), d) dulinn klasi (e. latent cluster), og e) virkur klasi (e. working cluster). Nálgun Enrights varð fyrir valinu vegna pess að hún miðast við svæðisbundna klasa, gerir skýran greinarmun á milli próunarskeiða auk pess sem nálgunin hefur verið notuð í öðrum rannsóknum (Ingstrup og Damgaard, 2013). Útfærsla höfunda á hinum fimm skeiðum í próun klasa (sjá mynd 1) tekur mið af umfjöllun Enrights um pessi skeið en ekki er um beina pýðingu á ensku hugtökunum að ræða (2003, bls. 104):

Skeið 1 - Ósk um klasa svarar til klasa sem hefur verið nefndur af einhverjum klasaaðila sem hugmynd eða ósk, en hvorki er nægilegur fjöldi aðila í klasanum né neitt samspil eða klasasamstarf á milli peirra.

Skeið 2 - Stefnt að klasa svarar til klasa sem hefur verið tilgreindur eða skilgreindur af einhverjum klasaaðila, t.d. hinu opinbera, í stefnu um stofnun klasa, en bæði er virkni og fjöldi aðila í klasanum ófullnægjandi og pað er tæplega til staðar neitt samspil eða klasasamstarf.

Skeið 3 - Vísir að klasa svarar til klasa sem er kominn á legg og á sér áhugasama klasaaðila, bæði einkaaðila og opinbera aðila. Рað eru vísbendingar um nægilegan fjölda og virkni aðila í klasanum en ekki mikið um pað sem kalla má skilgreint klasasamstarf.

Skeið 4 - Dulinn klasi svarar til klasa sem er sannanlega til staðar á viðkomandi svæði og klasaaðilar eru virkir hver um sig, bæði einkaaðilar og opinberir aðilar. Samsöfnunaráhrif eru talsverð og pekkingarmiðlun á sér stað á milli aðila en klasinn hefur ekki próað með sér klasasamstarf, t.d. með starfsemi klasaframtaka.

Skeið 5 - Virkur klasi svarar til klasa sem er til staðar á viðkomandi svæði og klasaaðilar eru virkir hver um sig, bæði einkaaðilar og opinberir aðilar. Samsöfnunaráhrif eru mikil og öflug pekkingarmiðlun á sér stað á milli aðila. Klasamiðuð viðskiptapróun er innan klasans og á vettvangi hans er umtalsvert klasasamstarf, t.d. með starfsemi virkra klasaframtaka.

Pessi flokkun í fimm skeið í próun klasa takmarkast af peim fræðilega grundvelli sem er að baki nálgun Enrights (2003) og einnig af pví að um útfærslu höfunda er að ræða á peirri nálgun. Tilgangurinn er fyrst og fremst að gera mögulegt að greina á milli aðskildra próunarskeiða og varpa pannig áhugaverðu ljósi á stöðu tónlistarklasa á Íslandi.

Í priðja lagi er svo rýnt í stöðu og aðstæður íslenska tónlistarklasans út frá demanti Porters (1990), en verkfærið er viðurkennt og notað í greiningum af pessu tagi (Ketels og Sölvell, 2006). Til að auðvelda lesendum að átta sig á verkfærinu er pví lýst stuttlega. Demanturinn skiptist í fjóra meginfleti, sjá mynd 2 hér að neðan. Fyrst má nefna framleiðslupætti klasans par sem einkum er horft til umfangs og aðgengis að hvers kyns aðföngum og framleiðslupáttum sem og sérhæfni peirra. Næst er vikið að eftirspurnaraðstæðum klasans par sem rýnt er pætti sem ýta undir eftirspurn eftir vörum og pjónustu sem er á pví svæði sem um er að ræða. Pessar tvær víddir eru settar fram lárétt í demantinum. Lóðrétt eru líka tvær víddir. Ef litið er til aðstæðna fyrir stefnumiðaðan rekstur pá snýst greiningin um að draga fram hversu mikið svigrúm í regluverki og aðstæðum er til stofnunar fyrirtækja, próunar á stefnu peirra, skipulagi og pátttöku í samkeppni. Að lokum er í demantinum litið til greiningar á tengdum greinum en hún opnar augun fyrir peim tækifærum sem fyrirtæki og stofnanir á svæðinu hafa á sviði samvirkni og tenginga við aðila í öðrum atvinnugreinum (Porter, 1990; Hálfdán Karlsson og Runólfur Smári Steinpórsson, 2009). Pessi greining takmarkast einnig við pann grundvöll sem hún byggist á, p.e. kenningar og pann skóla í klasafræðum sem kenndur er við Michael E. Porter. Hér að framan hefur verið gerð grein fyrir pessari nálgun og vísað til pess að til eru fleiri skólar og leiðir til að rýna í klasa. Eins og bent var á í inngangi er greiningin gerð til að fá fram upplýsingar um einkenni og áskoranir tónlistarklasa á Îslandi og takmarkast niðurstöður og umfjöllun við pað dæmi. Niðurstöðurnar hafa hagnýtt gildi fyrir tónlistarklasann og eru innlegg í fræðilega umræðu um klasa í litlu fámennu landi, eins og vikið var að í inngangi. 


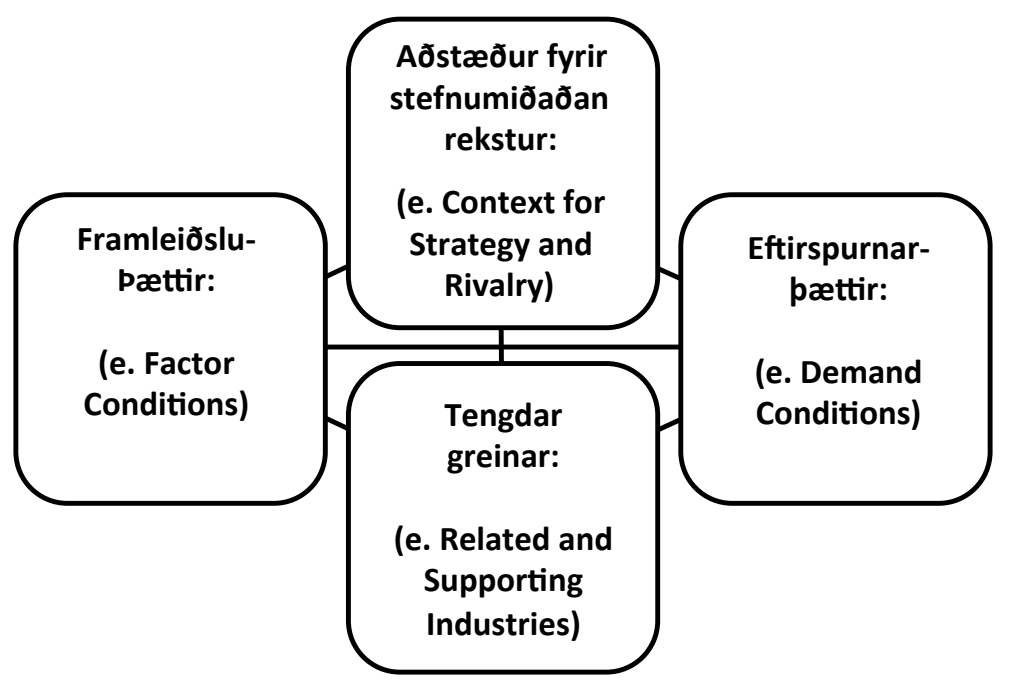

Mynd 2. Demantur Porters (byggt á Porter, 1990)

Í pessum kafla hefur verið gerð grein fyrir pví hvernig rannsókninni og gagnaöfluninni hefur verið háttað. Rannsóknin er byggð á fyrirliggjandi gögnum um forsendur fyrir klasa í tónlist. Athugunin á gögnunum hefur skilað klasakorti sem sýnir tónlistarklasann, klasinn er einnig metinn út frá nálgun Enrights (2003) yfir fimm möguleg skeið í klasapróun og að endingu er gerð greining á klasanum út frá demanti Porters (1990). Nú verður vikið að niðurstöðum.

\section{Vísir að tónlistarklasa á Íslandi}

Viðfangsefni greinarinnar er að skoða tónlist á Íslandi út frá spurningunni um hvort finna megi klasa á pessu sviði hérlendis út frá nálgun klasafræðanna sem stuðst er við og með hliðsjón af peim rannsóknum á tónlistarklösum sem hefur verið lýst. Eftirfarandi eru niðurstöður rannsóknarinnar.

\subsection{Forsendur fyrir klasa í tónlist á Íslandi}

Á Íslandi er heildarvelta tónlistariðnaðarins um 15 milljarðar á ári, en pað er um 1\% af landsframleiðslu (Ágúst Einarsson, 2013). Við tónlistariðnaðinn á Íslandi starfa um 1.500 manns hið minnsta, pað eru peir sem starfa beint við tónlist en sú tala er mun hærri ef afleidd störf eru einnig talin, en ekki liggja fyrir tölur um hversu margir starfa óbeint við tónlistariðnaðinn. Fyrir utan pá sem starfa beint við tónlist er einnig fjöldi fólks sem iðkar listina reglulega (Ágúst Einarsson, 2013). Púsundir Íslendinga syngja í peim fjölmörgu kórum sem starfandi eru á Íslandi að ógleymdum peim sem leika í lúðrasveitum og iðka aðra tónlist af margvíslegu tagi. Einnig leikur og syngur fjöldi manna í hljómsveitum sér og öðrum til ánægju pó að peir starfi ekki sem tónlistarmenn. Samkvæmt upplýsingum frá Félagi íslenskra hljómlistarmanna voru 750 manns skráðir í félagið árið 2016 (FÍH, e.d). Jafnframt voru 550 félagsmenn skráđir í FT, Félag tónlistarskólakennara (FT, e.d.), 350 manns skráðir í FTT, Félag tónskálda og textahöfunda (FTT, e.d.) og 550 félagsmenn skráðir í Tónskáldafélag Î́slands (TÍ). Pess ber pó að geta að félagsmenn pessara félaga skarast að nokkru leyti pví sum peirra eru stéttarfélög en önnur hagsmunafélög (FÍH, e.d.). 
Tafla 1. Opinber framlög til tónlistar (Fjárlög, 2011-2015).

\begin{tabular}{lrrrr}
\hline & $\mathbf{2 0 1 1}$ & $\mathbf{2 0 1 2}$ & $\mathbf{2 0 1 3}$ & $\mathbf{2 0 1 4}$ \\
\hline Upphæð í milljónum alls & $\mathbf{8 9 7}$ & $\mathbf{1 0 6 9}$ & $\mathbf{1 1 7 0}$ & $\mathbf{1 1 3 5}$ \\
\hline Stofnanir alls & 714,9 & 858,5 & 901,8 & 930,2 \\
Sinfóníuhljómsveit Íslands & 714,9 & 858,5 & 901,8 & 930,2 \\
Opinberir sjóðir alls & $\mathbf{1 2 9 , 5}$ & $\mathbf{1 5 4 , 8}$ & $\mathbf{1 9 2 , 7}$ & $\mathbf{1 6 0 , 2}$ \\
Launasjóður tónskálda & 40,6 & 55,4 & 57,3 & 59,2 \\
Launasjóður tónlistarflytjenda & 45,3 & 52,4 & 54,3 & 56,1 \\
Tónlistarsjóður & 43,6 & 47 & 81,1 & 44,9 \\
Önnur verkefni alls & $\mathbf{5 2 , 6}$ & $\mathbf{5 6}$ & $\mathbf{7 5 , 6}$ & $\mathbf{4 4 , 6}$ \\
Iceland Airwaves & 5 & 4,7 & 2 & 0 \\
Tónlist fyrir alla & 6,3 & 6,2 & 6 & 0 \\
ÚTÓN & 22,7 & 26 & 46 & 26 \\
Tónlistarfl. við kirkjulegar athafnir & 0,9 & 0,9 & 0,9 & 0,9 \\
Tónlistarflutningur við jarðarfarir & 4,3 & 4,3 & 4,3 & 4,3 \\
Íslenska tónverkamiðstöðin & 10,4 & 10,2 & 13,4 & 13,4 \\
Félag kvikmyndatónskálda & 0 & 0,5 & 0 & 0 \\
Tónskáldafélag Íslands & 0 & 1 & 1 & 0 \\
Ung Nordisk Musik & 0 & 0,2 & 0 & 0 \\
Biophilia & 0 & 2 & 2 & 0 \\
Reykholtshátíð & 1 & 0 & 0 & 0 \\
Músík í Mývatnssveit & 1 & 0 & 0 & 0 \\
Sumartónleikar í Skálhoti & 1 & 0 & 0 & 0 \\
\hline
\end{tabular}

Heimilid: Freyja Gunnlaugsdóttir (2015).

Aðgerðir stjórnvalda skipta miklu máli fyrir tónlistariðnaðinn. Í töflu 1 má sjá yfirlit yfir opinber framlög til tónlistariðnaðarins á árunum 2011-2014. Stærstur hluti pessara framlaga kemur frá mennta- og menningarmálaráðuneytinu en einnig er hluti frá atvinnuvegaog nýsköpunarráđuneyti (Margrét Sigrún Sigurðardóttir og Tómas Young, 2011). Framlög til tónlistar virðast fremur lág ef miðað er við heildarframlög til annarrar menningarstarfsemi og skapandi greina. Í skýrslunni „Skapandi greinar sýn til framtíðar" sem unnin var fyrir mennta- og menningarmálaráðuneytið árið 2012 kemur fram að í fjárlögum árið 2012 hafi heildarframlög til skapandi greina verið 7095 milljónir en af peim framlögum hafi 15,1\% runnið til tónlistarlífsins. Árið áður hafði pað hlutfall verið 12,7\% (Ása Richardsdóttir, 2012).

\subsection{Kortlagning tónlistarklasans}

Til að átta sig nánar á pví hvort klasi sé til staðar hér á landi er hér sett fram klasakort sem byggist á gögnum rannsóknarinnar. Útfærslan á klasakortinu er gerð af höfundum, en aðferðin tekur mið af klasakorti Porters (Runólfur Smári Steinpórsson, 2016a) eins og lýst var í kaflanunum um rannsóknaraðferðina hér að ofan. Kortlagning á klasa með grafískum hætti getur eðli málsins ekki verið mjög nákvæm en gefur góða yfirsýn yfir viðkomandi klasa og pað umhverfi sem hann starfar innan. Í klasakortlagningu er horft til samspilsins á milli klasaaðila og peirrar verðmætasköpunar sem verður til innan klasans.

Á klasakorti af íslenska tónlistarklasanum (sjá mynd 3) má sjá flokkana sem vísa til helstu aðila klasans. Við kortlagninguna er varpað ljósi á mikilvægustu aðila klasans. Í miðju klasakortsins er kjarnastarfsemi tónlistarklasans. Meginflokkarnir eru sköpun tónlistar, framleiðsla tónlistar, tónlistarflutningur og tónlistarkennsla. Forsenda fyrir kjarnastarfsemi er sjálft tónlistarfólkið, tónskáld og flytjendur. Tónskáldin koma að sköpun tónlistar og að framleiðslu tónlistar ásamt aðstoðarfólki og útgefendum. Birtingarmynd kjarnastarfseminnar er einnig lifandi tónlistarflutningur par sem tónlistarmenn eru í aðalhlutverki og miðla tónlistinni til áheyrenda. Í miðju kortsins eru einnig settir lykilinnviðir 
eins og hljóðver og tónleikasalir, enda er pað par sem tónlistin er annars vegar tekin upp og flutt beint.

Í samræmi við hefðbundna framsetningu á klasakorti er kortið lýsandi fyrir ferli verðmætasköpunar. Vinstra megin á klasakortinu er að finna pá sem koma að gerð tónlistar, p.e. tónlistarfólkið sjálft, og hvaða aðföng parf til pess að tónlistin geti orðið til. Par má nefna pá sem eru sérhæfðir í að gera við og gera hljóðfæri tiltæk til notkunar. Einnig peir sérfræðingar og aðilar sem hafa til reiðu tæknibúnað og veita tæknipjónustu svo unnt sé að framleiða og flytja tónlist. Hægra megin á klasakortinu sjáum við aftur á móti pá sem skapa skilyrði fyrir hina sem vilja njóta tónlistar. Petta eru peir aðilar sem ýta undir eftirspurnina á peirri pjónustu sem kjarnaaðilar klasans geta veitt. Hér má nefna pá sem skapa skilyrði fyrir tónlistarflutning til tónlistarverðlauna, aðila sem koma að skipulagningu tónleika og tónlistarhátíða, auk peirra sem hafa atvinnu af pví að fjalla um tónlist og tónlistarviðburði á faglegan hátt. Einnig má nefna að tengdir klasar geta haft mikil áhrif á forsendur fyrir velgengni klasa. Í klasakortinu er stuttlega vikið tengdum klösum en ekki er útfært frekar hvernig pessir klasar vinna með tónlistarklasanum.

Efsta röðin yfir aðila á klasakortinu eru peir sem veita sérhæfða og rekstrartengda pjónustu fyrir klasann. Petta eru sérhæfðir aðilar úr tengdum atvinnugreinum. Fyrst er að nefna pá sem eru reiðubúnir að taka fjárhagslega ábyrgð á útgáfu, afla styrkja og sinna rekstri eða pjónustu við rekstur á sviði tónlistar, t.d. á sviði höfundaréttar og hugverkaverndar. Svo er hópur fyrirtækja og pjónustuaðila sem m.a. sérhæfir sig í hönnun á vörum og pjónustu á sviði tónlistar, p.m.t. á kynningarefni fyrir tónlistarmenn og tónlistarafurðir. Svo er sérhæfð pjónusta við markaðssetningu og sölu tónlistar og tónlistarviðburða. Jafnframt sérhæfðir aðilar í dreifingu tónlistar.

Neðst á klasakortinu fyrir neðan kjarnann eru mikilvægar grunnstoðir klasans. Par má nefna mismunandi aðila sem telja má til stjórnvalda, menntastofnana og stéttarfélaga tónlistarmanna. Menntastofnanir gegna lykilhlutverki í pví að byggja upp öflugt tónlistarlíf með pví að veita umgjörð fyrir kennslu og rannsóknir á sviði tónlistar. Menntastofnanir eru í lykilhlutverki fyrir atvinnugreinina, bæði hvað varðar menntun og nýliðun á tónlistarfólki og sem vinnustaðir tónlistarfólks í tónlistarkennslu. Stjórnvöld gegna einnig mikilvægu hlutverki í tónlistariðnaðinum pví stofnanir og listamenn eru oft háðar ákvörðunum og afskiptum hins opinbera, m.a. opinberum framlögum. Stefna stjórnvalda í málefnum tónlistar getur pví haft mjög mikil áhrif á pað hvernig tónlistarlíf í landinu próast á hverjum tíma og hvort skilyrði eru fyrir tónlistarklasann til pess að vaxa og dafna.

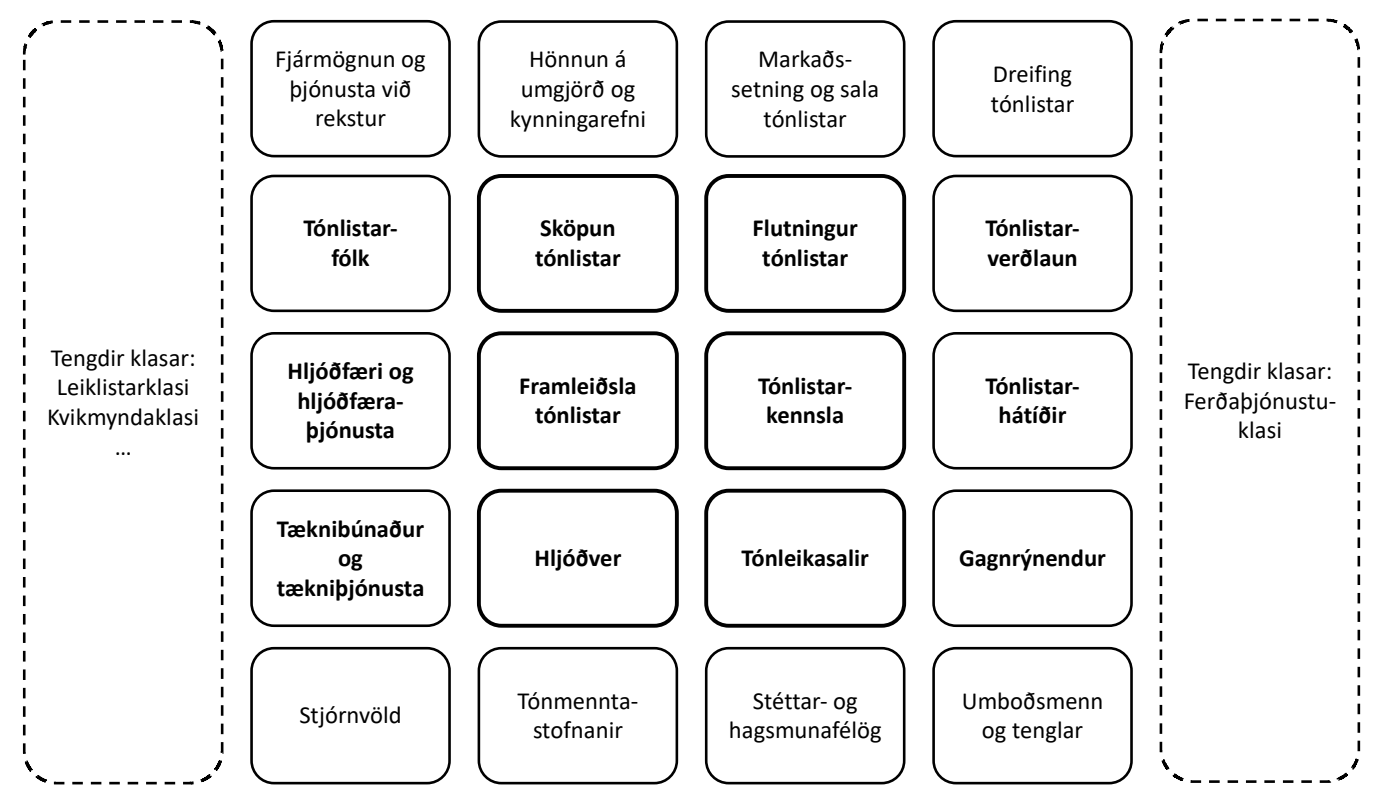

Mynd 3. Kort af tónlistarklasa (eigin útfærsla, byggð á gögnum rannsóknarinnar) 
Peir sem starfa innan klasans geta bæði verið keppinautar og samstarfsfólk. Pví parf oft umboðsmenn og tengla til að styðja við og efla starfið innan klasans. Heilbrigð samkeppni innanlands styður við gróskuna í klasanum og pegar kemur að útflutningi á tónlist geta verið forsendur fyrir samstarfi sem skilar verðmætum. Tónlistarmenn á Íslandi búa við mikla nálægð hver við annan og samvinna og samnýting er algeng á ákveðnum páttum líkt og tæknibúnaði, hljóðfærum og öðru. Lítið aðgengi er að fjármagni innan greinarinnar og oft fara tónlistarmenn pá leið að hjálpast að pegar svo ber undir. Pessi nána samvinna milli tónlistarmanna á Íslandi styrkir tónlistarlífið og skapar sérstæðar aðstæður hér á landi.

Pegar kemur að landfræðilegri hlið klasans kemur í ljós veruleg sampjöppun. Рað pýðir að margar af helstu stofnunum tónlistarlífsins eru á svo til sama stað í miðbæ Reykjavíkur. Sinfóníuhljómsveit Íslands, Íslenska óperan og Stórsveit Reykjavíkur hafa aðsetur sitt í Hörpu. Jafnframt eru margar tónlistarhátíðir sem fara fram í Hörpu líkt og Jazzhátíð í Reykjavík, Myrkir músíkdagar, Reykjavík Midsummer Music, Iceland Airwaves og fleiri hátíðir og tónleikaraðir. Við opnun Hörpu vorið 2011 eignuðust Íslendingar í fyrsta sinn tónleikahús sem er samkeppnishæft á alpjóðlegum mælikvarða og hefur pað reynst mikið gæfuspor fyrir tónlistarlíf í landinu. Pað má pví segja að hjarta tónlistarklasans sé að finna við Austurbakkann í Reykjavík, í Hörpu.

\subsection{Staða tónlistarklasans úr frá próunarskeiðum klasa}

Ef litið er til tónlistarklasans á Íslandi er ekki að finna sérstakar hugmyndir eða stefnu um stofnun eða tilurð hans, enda eru pau skref ekki nauðsynleg forsenda klasapróunar. Rannsóknin sem hér er greint frá bendir hins vegar til pess að vísir að klasa sé til staðar. Pað felur í sér að líta megi svo á að tónlistarklasinn sé á priðja skeiði með hliðsjón af líkani Enrights (2003) sem gerð var grein fyrir í 2. kafla.

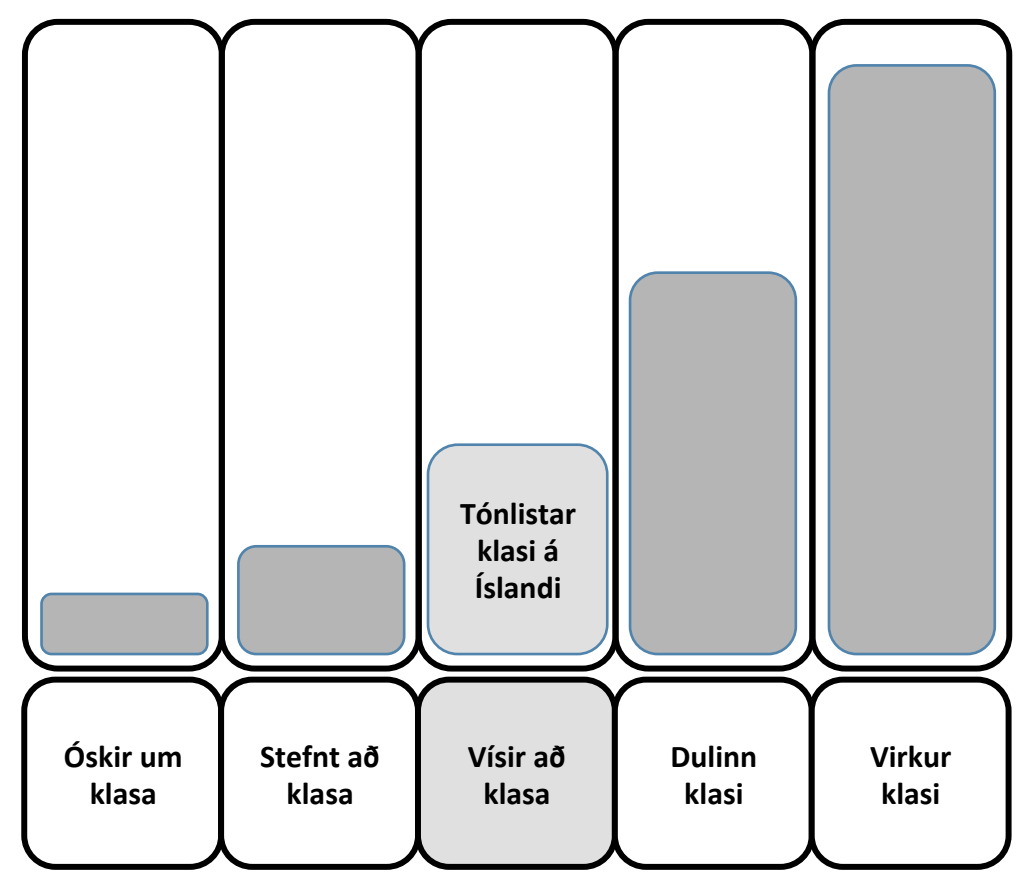

Mynd 4. Tónlistarklasinn á priðja skeiði í próun klasa (útfærsla höfunda).

Раð sem einkennir umrætt skeið, vísi að klasa, er að í umhverfi klasans eru forsendur fyrir verðmætasköpun og arðbæran rekstur en hins vegar vantar upp á nægilegan péttleika (krítískan massa) og samvirkni til að starfsemin sé eins og hún best getur orðið. (Enright, 2003). Klasakortið (sbr. mynd 3) sýnir að tónlistarklasinn á Íslandi er ótvírætt kominn nokkuð á veg en langt er í að hann hafi náð fullum proska hvað varðar virkt og öflugt kla- 
samiðað samstarf (Ketels og Memedovic, 2008) og pví virðist rökrétt að álykta að klasinn sé á priðja skeiðinu í próun klasa.

Ef litið er 50 ár aftur í tímann má sjá að umhverfi tónlistar og staða tónlistarmanna hefur breyst mikið. Peim hefur fjölgað umtalsvert sem gera tónlist að lifibrauði sínu. Samhliða hefur allt umhverfi tónlistar tæknilega séð breyst mikið og stutt er síðan tónlistarhúsið Harpa, sem landfræðilega er í miðju klasans, var reist. Mögulega er einn lykilinn að pessari klasapróun að finna í tónlistarskólum sem starfræktir hafa verið víða um land um nokkurra áratuga skeið. Pessir skólar hafa pó átt við fjárhagserfiðleika að etja í starfsemi sinni og purft að glíma við margar áskoranir. Svo er enn í dag en próunin hefur verið í rétta átt og íslenskt tónlistarfólk nýtur nú meiri eftirspurnar eftir list sinni en áður.

\subsection{Greining á aðstæðum klasans og viðfangsefnum}

Til að gera mögulegt að svara priðju rannsóknarspurningunni um hver séu brýnustu viðfangsefnin sem tónlistarklasinn á Íslandi stendur frammi fyrir er gagnlegt að rýna í aðstæður og grundvallarpætti klasans. Byggt er á demanti Porters sem verkfæri sbr. mynd 2 og umfjöllun í aðferðafræðikaflanum.

Pegar rýnt er í tónlistarklasann koma ýmsir veikleikar í ljós en greiningin dregur líka fram sterka pætti. Fjallað er um einstaka pætti demantsins í punktaformi og eðlilega kunna pættirnir sem dregnir eru fram að skarast eitthvað.

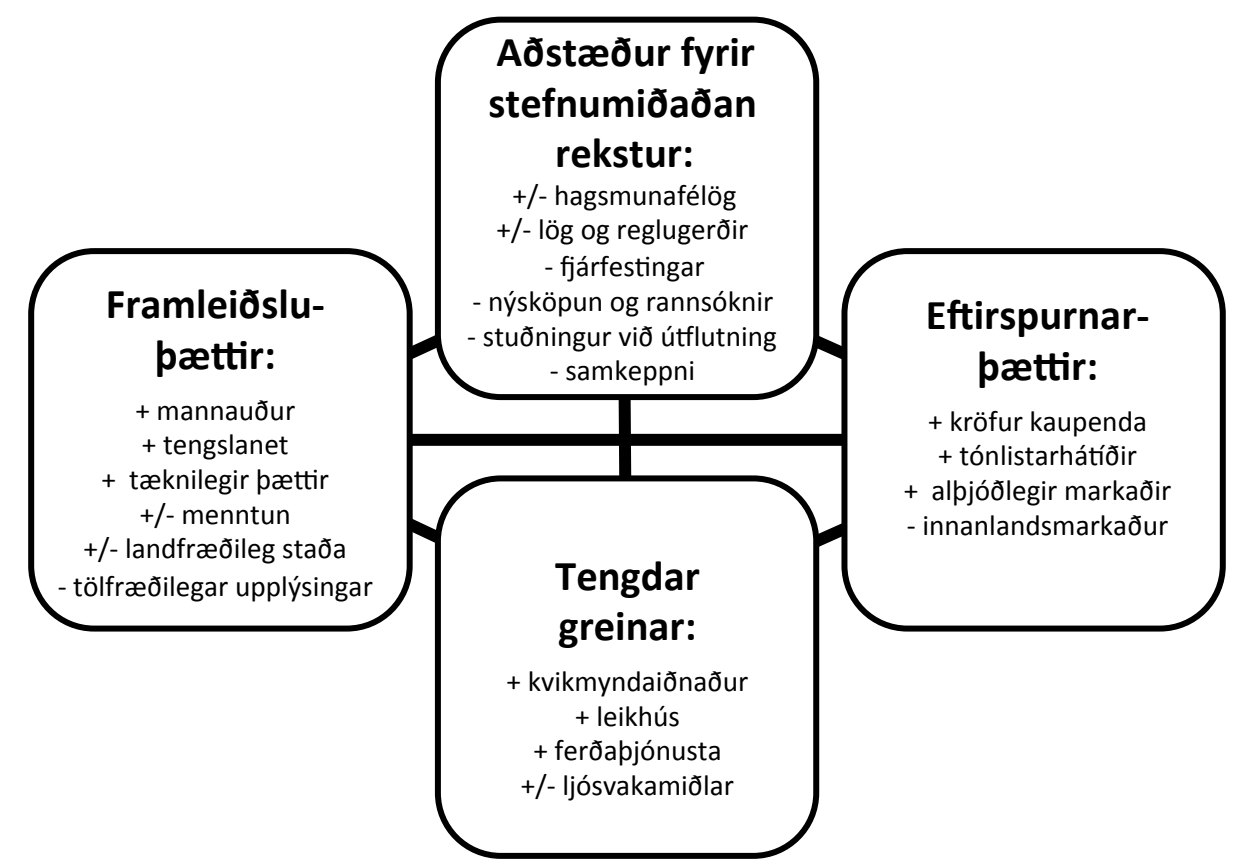

Mynd 5. Greining á aðstæðum tónlistarklasans

\subsubsection{Framleiðslupættir}

Varðandi framleiðslupætti og aðgengi að peim pá er marga peirra að finna sem endurspegla jákvæðar aðstæður:

Mannauður: Menntunarstig er hátt innan tónlistariðnaðarins og margt tónlistarfólk sem sækir háskólamenntun sína til útlanda snýr aftur til Íslands að námi loknu. Petta unga tónlistarfólk vinnur langa vinnudaga og reynir að ná fótfestu og sjá fyrir sér sem tónlistarmenn (Freyja Gunnlaugsdóttir, 2015; Jóhann Ágúst Jóhannsson, 2014). Aðgengi að hæfileikaríku, vel menntuðu tónlistarfólki er pví gott í tónlistariðnaðinum (Mennta og- menningarmálaráðuneytið, 2013).

Tengslanet: Íslenskir tónlistarmenn hafa náð sér á strik í alpjóðlegum tónlistariðnaði og rutt brautina fyrir pá sem á eftir koma. Útgáfufyrirtæki eru opin fyrir íslensku tónlistar- 
fólki og erlend fyrirtæki hafa sent starfsmenn á tónlistarhátíðir á Íslandi til pess að leita uppi íslenskt hæfileikafólk (Mennta- og menningarmálaráðuneytið, 2013).

Tæknilegir pættir: Á Íslandi er að finna tæknilega fullkomin upptökuver líkt og Gróðurhúsið, Sundlaugina, Stúdíó Sýrland og fleiri. Erlendir tónlistarmenn koma hingað til lands til pess að hljóðrita tónlist. Skilyrði til framleiðslu og upptöku á Íslandi eru góð sem er líka jákvætt fyrir tengda klasa.

Menntun: Tónlistarmenntun hefur verið frekar almenn á Íslandi og aðgengi að henni gott, en 88 tónlistarskólar starfa um allt land. Framhaldsmenntun í Reykjavík hefur verið nokkuð sterk prátt fyrir pröngan kost (Reykjavíkurborg, 2014; STS, e.d.). Árið 2001 tók tónlistardeild Listaháskóla Íslands til starfa og er hún eina tónlistardeildin á háskólastigi (Ágúst Einarsson, 2013; Reykjavíkurborg, 2014; Mennta- og menningarmálaráðuneytið, 2000). Menntaskóli í tónlist er nýstofnaður og framhaldsmenntun í tónlist orðin hluti af almenna skólakerfinu (MÍT, e.d.).

Landfræðileg lega: Íslenskir tónlistarmenn purfa að bera mikinn kostnað vegna ferða og flutnings á hljóðfærum milli landa. Markaður fyrir tónlist á Íslandi er einnig mjög lítill í alpjóðlegum samanburði og pví er mikilvægt fyrir íslenskt tónlistarfólk að ná árangri á erlendum mörkuðum. Staðsetning Íslands mitt á milli Evrópu og Bandaríkjanna hefur ákveðna kosti í för með sér og gerir landið að pægilegum viðkomustað fyrir tónlistarfólk á tónleikaferðalögum milli heimsálfanna.

Fjárhagsleg staða: Fjárhagslega er tónlistariðnaðurinn erfiður og opinber framlög til tónlistar á Íslandi hafa staðið í stað og dregist saman að raungildi, sbr. töflu 1 hér að framan. Erfitt hefur reynst að fjármagna ný verkefni og styrkir frá einkaaðilum hafa dregist saman. Pau störf sem tónlistarmenn vinna eru oft láglaunastörf og margir neyðast til að sjá sér farborða með annarri vinnu (Fjárlög, 2011-2015; Freyja Gunnlaugsdóttir, 2015).

Tölfræðilegar upplýsingar: Tölfræðilegar upplýsingar um atvinnugreinina eru takmarkaðar og pví er erfitt að ná utan um umfang hennar. Úrbætur á pessu eru mikilvægar fyrir greinina og öflun pekkingar um hana.

\subsubsection{Aðstæður fyrir stefnumiðaðan rekstur}

Hér er marga pætti að finna sem endurspegla áskoranir en einnig má sjá að samvirkni og samstaða skiptir máli fyrir greinina:

Stéttar- og hagsmunafélög: Stéttarfélög tónlistarmanna ásamt hagsmunafélögum mynda eina af grunnstoðum tónlistarklasans. Félag íslenskra hljómlistarmanna semur um launakjör tónlistarmanna og gætir hagsmuna peirra. Ýmis önnur hagsmunafélög vinna að pví að styrkja stöðu tónlistarmanna eins og Félag íslenskra tónlistarmanna, Félag Tónskálda og textahöfunda, Tónskáldafélag Íslands og fleiri félög (FÍH, e.d.; FÍT, e.d.; FTT, e.d.).

Lög og reglugerðir: Lagaramminn á sviði tónlistar er ekki skýr og eftirliti virðist ábótavant. Dæmi eru um ágreining um lagatúlkun á milli ríkis og Reykjavíkurborgar varðandi lög um tónlistarskóla (Lög nr. 75/1985; Höfundalög nr. 73/1972; Freyja Gunnlaugsdóttir, 2015). Höfundarréttur tónlistarmanna er enn fremur illa varinn fyrir ólöglegu niðurhali og fleiri brotum á höfundarrétti (Lög nr. 75/1985; Höfundalög nr. 73/1972).

Fjárfestingar og skattamál: Víða er veittur skattaafsláttur vegna styrkja sem renna til menningar og lista. Afsláttur af pessum toga hefur ekki verið veittur á Íslandi en erlendis hefur hann orðið til pess að hvetja fyrirtæki og fjárfesta til að veita styrki til menningartengdra verkefna (Ása Richardsdóttir, 2012; Ágúst Einarsson, 2013).

Alpjóðleg samkeppni: Sú staðreynd að markaður fyrir tónlist á Íslandi er lítill ýtir undir útrás á erlenda markaði. Breytt tækni getur hjálpað í pví ferli og dæmi eru um að tónlistarmenn hafi náð alpjóðlegri athygli á örskammri stundu í gegnum Youtube, m.a. hérlendir tónlistarmenn á borð við Ásgeir Trausta.

Samkeppni og samstarf: Vegna smæðar samfélagsins er tónlistariðnaðurinn á Íslandi lítill og nálægðin mikil. Klasakortið (mynd 3) varpar ljósi á að ein af meginforsendum fyrir blómlegu tónlistarlífi á landinu er náin samvinna á milli tónlistarmanna og stofnana innan 
tónlistariðnaðarins. Hins vegar kann að vanta samkeppni sem skerpir tónlistarfólkið enn frekar, pótt mikil keppni sé um pá athygli og pað litla fjármagn sem til staðar er fyrir tónsköpun og tónlistarflutning, og er pá bæði átt við opinbera styrki og einkafjármagn.

\subsubsection{Eftirspurnarpættir}

Pegar kemur að eftirspurn eftir íslenskri tónlist pá eru aðstæður bæði jákvæðar og neikvæðar:

Kröfur/smekkur kaupenda: Íslenskir hlustendur hafa reynst kröfuharðir og vilja hlusta á góða tónlist í gæðaflutningi. Sama virðist gilda um áheyrendur annars staðar. Á undanförnum árum hafa íslenskir tónlistarmenn öðlast sífellt fleiri hlustendur erlendis og par er að finna stærri hluta af neytendahópi íslenskrar tónlistar en innanlands (Mennta- og menningarmálaráðuneytið, 2013).

Innanlandsmarkaður: Innanlandsmarkaður er lítill sökum smæðar pjóðarinnar. Prátt fyrir pað er mikil eftirspurn eftir tónlist sem eflir tónlistarlífið og eykur fjölbreytni pess (Mennta- og menningarmálaráðuneytið, 2013).

Tónlistarhátíðir: Fjöldi tónlistarhátíða fer fram á Íslandi og fólk alls staðar að sækir pær. Pessar hátíðir hafa auðgað íslenskt tónlistarlíf og laðað að fjölda erlendra gesta sem kemur hingað til lands til að njóta íslenskrar tónlistar. Hátíðirnar skila jafnframt miklum hagnaði til samfélagsins (Ása Richardsdóttir, 2012; Margrét Sigrún Sigurðardóttir og Tómas Young, 2011; Ævar R. Hafpórsson, 2013; Tómas Young, 2013).

Alpjóđlegur markaður: Mikill áhugi og eftirspurn er eftir íslenskri tónlist og tónlistarmönnum á alpjóðlegum markaði. Рað er að pakka góðu orðspori íslenskra tónlistarmanna, kynningarstarfi og tengslavinnu og peirri jákvæðu ímynd sem íslensk tónlist hefur nú í samfélagi pjóðanna (Tómas Viktor Young, 2008; ÚTÓN, e.d).

\subsubsection{Tengdar greinar}

Innan tengdra greina er marga pætti að finna sem benda til pess að hér ríki jákvæðar aðstæður:

Kvikmynda- og leikhúsiðnaðurinn: Leikhúslíf og vinna við kvikmyndir tengist tónlist að mörgu leyti og margir tónlistarmenn starfa einnig innan leikhús- og kvikmyndaiðnaðarins. Tónlistarmenn semja tónlist fyrir leikhús og kvikmyndir og fjöldi hljóðfæraleikara vinnur við flutning hennar (Ágúst Einarsson, 2004, 2013).

Auglýsingaiðnaðurinn: Í flestum auglýsingum í útvarpi og sjónvarpi er leikin tónlist og skapar auglýsingaiðnaðurinn pannig fjölmörg störf fyrir tónlistarmenn sem starfa innan hans við gerð og flutning tónlistar (Freyja Gunnlaugsdóttir, 2015).

Ferðamannaiðnaðurinn er tengdur tónlistarlífinu á margan hátt. Fjölmargir ferðamenn leggja leið sína til Íslands til pess að njóta íslenskrar tónlistar og sækja tónlistarhátíðir og aðra tónleika hér á landi. Íslenskir tónlistarmenn hafa átt pátt í að skapa jákvæða mynd af Íslandi sem hefur áhrif á ferðamannaiðnaðinn. Pó nokkur samvinna hefur verið á undanförnum árum á milli tónlistarlífsins og ferðamannaiðnaðarins (Ása Richardsdóttir, 2012; Tómas Young, 2013).

Ljósvakamiðlar: Útvarp og sjónvarp leika stórt hlutverk við að koma tónlist á framfæri og dreifa henni. Útvarpið er mjög tengt tónlistarlífinu og dagskráin samanstendur að stórum hluta af tónlist. Internetið er jafnframt gríðarlega mikilvægt pegar kemur að kynningu og dreifingu á tónlist og aðgengi að tónlist er ótakmarkað í gegnum pað. Ýmsir erfiðleikar hafa pó komið upp í sambandi við verndun höfundaréttar og ólöglegt niðurhal er ennpá mjög algengt (Ágúst Einarsson, 2004, 2013).

Hér að ofan hefur verið gerð grein fyrir niðurstöðum rannsóknarinnar á tónlist á Íslandi út frá klasanálgun. Fjallað var um forsendur fyrir tónlistarklasa, sett var fram klasakort og bent á að samkvæmt greiningarlíkani Enrights (2003) megi álykta sem svo að á Íslandi sé vísir að tónlistarklasa. Að endingu bendir demantsgreining á klasanum til pess að hér séu jákvæðar aðstæður fyrir próun klasans pótt aðilar innan klasans purfi jafnframt að takast á við margar áskoranir. 


\section{Einkenni og áskoranir tónlistarklasans}

Eins og sett var fram í upphafi greinarinnar er viðfangsefni hennar að skoða tónlist á Íslandi sem klasa út frá eftirfarandi spurningum: 1) Hvernig má sjá og skoða tónlist á Íslandi sem klasa? 2) Hvernig hefur klasinn próast með hliðsjón af æviskeiði klasa? 3) Hver eru brýnustu viðfangsefnin svo klasinn nái að dafna og skila ávinningi?. Hér verða dregin saman svör við pessum spurningum og fjallað um pann lærdóm sem pessi rannsókn hefur skilað.

\subsection{Hvernig má skoða tónlist á Íslandi sem klasa?}

Niðurstöðurnar sem settar voru fram í klasakorti tónlistarklasans (mynd 3) benda til pess að sjá megi merki um klasa í tónlist á Íslandi. Klasakortið gefur vísbendingu um að á Íslandi sé virkur tónlistarklasi og pungamiðja hans sé í Reykjavík. Klasakortið byggist á pekktri fyrirmynd (Porter, 1998; Austrian, 2000; Runólfur Smári Steinpórsson, 2016a) og lýsingin á klasanum er til vitnis um að upplýsingar um tónlistarklasann eru í takti við kenningar um klasa (Porter, 1998; Ketels og Memedovich, 2008). Sú gróska sem klasakort tónlistarklasans sýnir gefur tilefni til að álykta að frekara klasastarf geti ýtt undir öflugt tónlistarlíf til frambúðar og rannsóknir á tónlistarklösum erlendis benda til pess að öflugir tónlistarklasar eigi pátt í að skapa bæði menningarleg og efnahagsleg verðmæti fyrir pað svæði sem peir starfa á (Power og Jansson, 2006). Рað má líka sjá að íslensk tónlist og íslenskir tónlistarmenn hafa notið velgengni og vinsælda á síðustu árum og pví má segja að sú jákvæða athygli hafi skapað dýrmæt tækifæri til frekari uppbyggingar atvinnugreinarinnar (Ágúst Einarsson, 2013). Til að nýta enn frekar slík tækifæri er mikilvægt fyrir bæði stjórnvöld og ekki síður pá aðila sem starfa innan greinarinnar að átta sig á hvað tónlistarklasi felur í sér og hvaða möguleikar geta skapast í markvissu klasasamstarfi (Lindquist o.fl., 2012). Líkur eru á að slíkt uppbyggingarstarf muni skila sér til baka til samfélagsins með margvíslegum hætti.

\subsection{Hvernig hefur klasinn próast?}

Eftir að hafa fengið ofangreindar vísbendingar um að klasa sé að finna í tónlist á Íslandi var gerð greining á stöðu hans með hliðsjón af próunarskeiðum klasa. Niðurstöðurnar í kaflanum hér að framan gefa til kynna að klasinn sé á priðja skeiði í greiningarlíkani Enrights (2003) og pannig megi tala um „vísi að klasa“. Petta pýdir að hér á landi sé klasi til staðar sem hefur forsendur til að eflast frekar ef skilyrði halda áfram að próast á jákvæðan veg (Enright, 2003). Eins og vikið var að í fræðilega hluta greinarinnar má líta á klasa sem náttúrulegt fyrirbæri sem próast yfir langan tíma (Ketels og Memedovic, 2008). Рað felur í sér að allir pættir í umhverfi klasa eru að próast og pátttakendum fjölgar með tilheyrandi jákvæðum ytri áhrifum (Sölvell, 2008). Varðandi próun tónlistarklasans má sjá að umfang og umhverfi tónlistarstarfs á Íslandi hefur breyst mikið á síðustu 50 árum og peim hefur fjölgað sem hafa atvinnu af tónlist. Sú niðurstaða að klasinn sé á priðja skeiði af fimm mögulegum skeiðum Enrights er m.a. sett fram í ljósi pess pað prjú síðastnefndu skeiðin eiga samsvörun við klasa sem eru komnir á legg. Fyrstu tvö skeiðin eru hins vegar undanfarar klasa sem eiga sér útgangspunkt í óskum, hugmyndum eða stefnu aðila um að klasi verði til. Slík áform um klasa eru hins vegar ekki staðfesting á að fyrir hendi séu forsendur eða aðstæður fyrir tilurð eða próun klasa og ef ekki eru viðunandi vaxtarskilyrði er ekki víst að tilraunir til klasastarfs skili árangri (Enright, 2003; Ingstrup og Damgaard, 2013). Niðurstaðan hér er að tónlistarklasi á Íslandi sé kominn á legg og rannsóknin bendir til pess að raunverulegur klasi hafi próast en að hann sé enn á pví stigi að vera pað sem hér er flokkað sem vísir að klasa (mynd 4) í niðurstöðum rannsóknarinnar. Prátt fyrir áhugaverða próun má sjá að klasinn stendur frammi fyrir erfiðum áskorunum. 


\subsection{Hver eru brýnustu viðfangsefni klasans?}

Greiningin á íslenska tónlistarklasanum sýnir að hann er enn á mótunarstigi en hafi prátt fyrir pað próast mikið á síðustu árum. Niðurstöður demantsgreiningar benda til pess að pað séu pegar margir pættir sem ýta undir jákvæða próun klasans en líka pættir sem vinna parf með til að efla klasann frekar. Demantsgreiningin varpar ljósi á aðstæður klasans og greinilegt er að meiri fjölbreytni og dýpt í peim páttum sem víddir demantsins draga fram skilar bæði virkari og öflugri klösum (Porter, 1990, 2008; Sölvell, 2008; Ketels, 2013).

Varðandi frekari próun á framleiðslupáttum klasans má benda á bæði rannsóknir og menntamál. Mikilvægt er að efla rannsóknir og stuðla að miðlun upplýsinga og pekkingar um klasann og tónlistariðnaðinn (Ágúst Einarsson, 2013; Margrét Sigrún Sigurðardóttir og Tómas Young, 2011). Ein megináskorunin er að stuðla enn frekar að sterku menntakerfi sem myndi skila vel menntuðu og hæfu tónlistarfólki til að starfa við atvinnugreinina. Par er sérstaklega mikilvægt að hlúa vel að nemendum sem stunda nám á framhaldsstigi og nýr Menntaskóli í tónlist er par mikilvægt skref. Jafnframt er pýðingarmikið að hlúa vel að tónlistarnámi og kennslu í Listaháskólanum, m.a. til að auka nýliðun meðal hljóðfærakennara í landinu (Freyja Gunnlaugsdóttir, 2015).

Greiningin á tónlistarklasanum dregur fram mikilvægi bæði samstarfs og samkeppni. Sú nánd og samvirkni sem ríkir innan tónlistargeirans eflir klasann og ýtir undir pau jákvæðu ytri áhrif sem er lykillinn að klasaávinningi (Ketels og Memedovic, 2008), en samkeppni er líka lykilatriði (Porter, 1990). Til að efla klasann getur verið gagnlegt að leggja áherslu á heilbrigða samkeppni um leið og leitað er leiða til að skapa tækifæri fyrir nýja kynslóð tónlistarmanna. Рað er lykilatriði að skapa aðstæður par sem nýir einstaklingar geta proskast sem listamenn og komið list sinni á framfæri. Mikilvægur liður í pví er að huga vel að réttindamálum tónlistarmanna, efla pekkingu á tónlistariðnaði og leggja áherslu á að efla gagnsæi um allt starf á sviði tónlistar. Jákvæð próun á pessu sviði getur stuðlað að enn betri aðstæðum fyrir gróskumikinn rekstur og starfsemi á sviði tónlistar. Rannsóknir á tónlistariðnaðinum hafa sýnt fram á að tónlist á Íslandi hefur haft veruleg áhrif á hagvöxt í landinu á síðustu árum (Ágúst Einarsson, 2013; Margrét Sigrún Sigurðardóttir og Tómas Young, 2011) og pað bendir til pess að tónlistariðnaðurinn sé umtalsverður og mikilvægt að leita leiða til að efla hann enn frekar.

Einn lærdómurinn af demantslíkaninu við klasagreiningu er að aðstæður sem ýta undir eftirspurn er mikilvægur lykill að velgengni klasa (Porter, 2008). Greiningin á eftirspurn bendir til pess að próunin hafi um margt verið jákvæð pótt lítið sé við pví að gera að á Íslandi sé lítill markaður í samanburði við alpjóðamarkaði. Pví er nauðsynlegt að hugsa út fyrir landsteinana. Hér er margs að gæta og hlutverk hins opinbera getur legið í að styðja við starf sem ýtir undir eftirspurn og einnig er mikilvægt að allir aðilar i klasanum hugi vel að pessum pætti út frá markaðsforsendum og með markaðsaðgerðum, auk pess að skoða möguleika á frekara klasasamstarfi (Ketels og Memedovic, 2008).

Greiningin á tónlistarklasanum undirstrikar líka mikilvægi pess að huga að tengdum greinum og páttum sem efla samspil og samvirkni á milli aðila. Lykilatriði í pessu efni er að ýta undir fjölbreytni og skapa tengsl um leið og hlúð er að pví að skapa umhverfi sem hvetur tónlistarfólk til dáđa. Í pessu efni er vert að huga að pví hvaða ávinningur hlýst af fyrirkomulagi eins og starfslaunum listamanna pví í mörgum tilfellum skila listamenn peim styrkjum margfalt til baka til pjóðarbúsins (Lög nr. 57/2009). Eins er spurning um getu og hlutverk tónlistarsjóðs (Lög nr. 76/2004). Pessi stuðningur hefur reynst mikilvægur og gefur greininni grundvöll sem sjá má sem hluta af grunnforsendum klasans, sbr. niðurstöðukaflann hér að framan. Рað má einnig sjá að svipað á við um tengdar greinar og allt sem styður við pær er líka liður í að efla tónlistarklasann. 


\section{Lokaord}

Í pessari grein hefur íslenskt tónlistarlíf verið skoðað frá sjónarhorni klasa til pess að fá fram mynd af próuninni og peim tækifærum sem hafa skapast á síðustu árum. Hér hefur verið sýnt fram á að á Íslandi er vísir að tónlistarklasa og bent á atriði sem bæði eru klasanum til frekari framdráttar og fela í sér áskorun á próunarbraut hans. Pær erlendu rannsóknir á tónlistarklösum sem skoðaðar voru í greininni, sbr. umfjöllun og heimildir í kafla 2.2, sýndu fram á mikilvægi pess að skapa góðar aðstæður fyrir listamenn, stofnanir og fyrirtæki innan tónlistarlífsins til pess að pað nái að vaxa og dafna. Рað er mikilvægt í próun tónlistarklasans á Íslandi að draga lærdóm af pessum rannsóknum en pær varpa ljósi á aðgerðir sem skiluðu sér margfalt til baka í menningarlegum og efnahagslegum hagnaði til samfélagsins á viðkomandi svæðum.

Pennan lærdóm af erlendu rannsóknunum mætti nýta til ávinnings fyrir íslenskt tónlistarlíf sem einnig hefur vakið eftirtekt og nýtur vissrar sérstöðu í alpjóðlegu tónlistarlífi. Pá sérstöðu væri líka athyglisvert að skoða betur og greina í frekari rannsóknum. Pá væri mikilvægt að skoða hvernig mætti nota pessa sérstöðu og pá jákvæðu athygli sem íslensk tónlist hefur fengið á síðustu árum á markvissan hátt til pess að styrkja íslenskt tónlistarlíf. Í pessu samhengi væri áhugavert að kanna leiðir til að efla klasasamstarf á sviði tónlistar, t.d. með sérstöku klasaframtaki (e. cluster initiative) en hérlendis er vaxandi reynsla af slíku starfi (Runólfur Smári Steinpórsson, 2016b). Með öflugu klasasamstarfi geta einstaklingar, fyrirtæki, stofnanir og stjórnvöld stuðlað að eflingu tónlistarklasans og unnið saman að pví að byggja upp próttmikið tónlistarlíf. •að væri jafnframt tilefni til enn frekari rannsókna á tónlistarklasanum. Samstarf af pessum toga myndi vafalaust styrkja stöðu íslenskrar tónlistar og tónlistarmanna í bæði innlendu og alpjóðlegu tónlistarlífi og stuðla enn frekar að áhugaverðu og fjölbreyttu menningarlífi hér á landi. Par er ekki síst mikilvægt að bera kennsl á pau menningarlegu verðmæti sem felast í íslenskri tónlist og pví góða orðspori sem íslenskir tónlistarmenn hafa byggt upp á síðustu árum.

Pessi grein um tónlistarklasa gefur innsýn í klasa á Íslandi. Framlag hennar takmarkast við tónlistarklasann sem er raundæmið í pessari rannsókn. Niðurstöður greinarinnar gefa ekki grundvöll til alhæfingar um klasa umfram dæmið sjálft. Рað er hins vegar áhugaverð spurning í frekari klasarannsóknum hérlendis hvort klasar séu á einhvern hátt öđru vísi pegar um lítil lönd eins og Ísland er að ræða. Mögulega hafa klasar hér á landi ákveðin sérkenni vegna smæðar og sérstöðu landsins. Slíkar niðurstöður eru líklegar til að vera áhugaverðar fyrir samanburð við önnur lönd, ekki síst pau sem eru svipuð Íslandi en einnig pau sem eru á margan hátt ólík. Pannig verður unnið áfram með niðurstöður pessarar rannsóknar og aðrar klasarannsóknir hérlendis sem eru í farvatninu með pað að markmiði að afla pekkingar á klösum í löndum og landsvæðum sem búa við sérstakar aðstæður vegna smæðar og sérstöðu.

\section{Heimildir}

Austin, J. E. (2000). Strategic Collaboration Between Nonprofits and Business. Non profit and Voluntary Sector Quarterly, 29 (1), 69-97.

Austrian, Z. (2000). Cluster case studies: The marriage of Quantative and Qualitative Information to Action., Economic Developement Quarter 14 (1), 97-110.

Ágúst Einarsson (2004). Hagræn áhrif tónlistar. Reykjavik: Viðskipta- og hagfræðideild Háskóla Íslands.

Ágúst Einarsson (2012). Menningarhagfræði. Bifröst: Háskólinn á Bifröst.

Ágúst Einarsson (2013). Tónlist veitir ánægju og velmegun. Vatnaskil í hrynheimum (bls. 24-32). Reykjavík: FTT.

Ása Richardsdóttir (2012). Skapandi greinar - sýn til framtíðar: Úttekt á stöðu og tillögur um bætt starfsumhverfi. Reykjavík: Mennta- og menningarmálaráđuneytið.

Beyers, W., Bonds, A., Wenzl, A. og Sommers, P. (2004). The economic Impact of Seattles Music Industry. Sótt 15. febrúar 2015 af http://www.seattle.gov/music/docs/Seattle_Music_StudyFinal.pdf.

Berg, L., Braun, E. og Winden (2014). Enhancing Urban Competitiveness through Innovative Growth Clusters, í P. Ni og Z. Qiongjie, (ritstj.), Urban Competitiveness and Innovation, (67-90). Cheltenham: Edward Elgar.

Berlin music commission (e.d.). Sótt 13. febrúar 2017 af http://www.berlin-music-commission.de/en/about/music-industry-facts.html. 
Bernard, M., Shankar Chaturvedi, R., Hill A., Maddox, C. og Schrimpf M. (2012). Tennessee Music Cluster. Boston: Harvard Business School.

Best, M. (2001). The New Competitive Advantage: A Renewal of American Industry. New York: Oxford University Press.

Boix, R., Lazzaretti, L., Hervás, J. L., og De Miguel, B. (2011). Creative clusters in Europe: a microdata approach. 51st European Congress of the Regional Science Association International. Barselóna: Ersa.

Caves, Richard E. (2000). Creative Industries: Contracts between art and commerce. Cambridge and London: Harvard University Press.

Chapain, C., Cook, P., De Propris, L. McNeill, S. og Mateos-Garcia, J. (2010). Creative Clusters and Innovation. London: NESTA.

Cluster Mapping, mapping a nation of regional clusters (e.d.). Sótt 8. apríl 2017 af: http://www.clustermapping.us/.

Clusters at your fingertips (e.d.). Sótt 8. Apríl 2017 af: http://www.clusterobservatory.eu/index.html.

Cruz, S.C. og Teixeira, A.A. (2010). The evolution of the cluster literature: shedding light on the regional studies - regional science debate. Regional studies, 44 (9), 1263-1288.

Delgado, M., Porter, M. E., og Stern, S. (2014). Clusters, convergence, and economic performance. Research Policy, 43 (10), 1785-1799.

Deutz, P. og Gibbs, D. (2008). Industrial Ecology and Regional Development: Eco-Industrial Development as Cluster Policy. Regional Studies, 42 (10), 1313-1328.

Eisenhardt, K. M. (1989). Building Theories from case study research. The Academy of Management review, 14 (4), 532-550.

Enright, M. J. (2003). Regional clusters: What we know and what we should know, í J. Bröcker, D. Dohse og R. Soltwedel (ritstj.). Innovation Clusters and Interregional Competition, (99-129). Berlin: Springer.

Forsætisráðuneytið (2008). Ímynd Íslands: Styrkur, staða og stefna. Reykjavík.

Florida, R. (2002). The Rise of the Creative Class, and How It's Transforming Work, Leisure and Everyday Life. New York: Basic Books.

FÍH (e.d.). Sótt 23. mars 2015 af http://felagsmenn.fih.is/default.aspx?PageID=68.

FÍT (e.d.). Um félagið. Sótt 23. mars 2015 af http://www.fiston.is/\#!about-us/cjg9.

FT (e.d.). Sótt 23. mars 2015 af http://ft.ki.is/?PageID=296.

FTT (e.d). Um félagið. Sótt 23. Mars 2015 af http://www.ftt.is/Um_felagid.

Ffowcs-Williams, I. (2012). Cluster development: The go-to handbook. New Zealand: Cluster Navigator.

Fjárlög fyrir árið 2011 nr. 169/2010.

Fjárlög fyrir árið $2012 \mathrm{nr}$. 185/2011.

Fjárlög fyrir árið 2013 nr. 162/2012.

Fjárlög fyrir árið 2014 nr. 149/ 2013

Fjárlög fyrir árið 2015 nr. 143/2014.

Freeman, J. A. (2010). Web-based collaboration, live musical performance and open-form scores. International Journal of Performance Arts and Digital Media, 6 (2), 149-170.

Freyja Gunnlaugsdóttir (2015). Framhaldsmenntun i tónlist á Íslandi: Próun, framtíð og stefna.(MS-ritgerð) Háskóli Íslands, Viðskiptafræðideild. Sótt 15. nóvember af https://skemman.is/bitstream/1946/21212/1/Framhaldsmenntun $\% 20 \% \mathrm{C} 3 \% \mathrm{AD} \% 20 \mathrm{t} \% \mathrm{C} 3 \% \mathrm{~B} 3 \mathrm{nlist} \% 20 \% \mathrm{C} 3 \% \mathrm{~A} 1 \% 20 \mathrm{C} 3 \% 8 \mathrm{Dslandi}$.pdf

Fromhold-Eisebith, M. og Eisebith, G. (2005). How to institutionalize innovative clusters? Comparing explicit top-down and implicit bottom-up approaches, Research Policy, 34, 1250-1268.

Gylfi Dalmann Aðalsteinsson og Helga Björg Ragnarsdóttir (2003). Iceland. Í Behind the music. Profiting from sound: A system's approach to the dynamics of the nordic music industry. Kaupmannahöfn: Nordic industrial fund.

Guðjón Örn Sigurðsson og Runólfur Smári Steinpórsson (2014a). Klasar og klasakenningar. Auður Hermannsdóttir, Ester Gústavsdóttir, Kári Kristinsson (ritstjórar) Vorráđstefna viðskiptafræðideildar (bls. 45-59). Reykjavík: Viðskiptafræðistofnun Háskóla Íslands.

Guðjón Örn Sigurðsson og Runólfur Smári Steinpórsson (2014b). Klasaframtök og vottun klasastarfs, í Ingjaldur Hannibalsson (ritstj.). Pjóđarspegillinn 2014 (bls. 1-15). Reykjavík: Félagsvísindastofnun Háskóla Íslands.

Hálfdan Karlsson og Runólfur Smári Steinpórsson (2009). Samkeppnishæfni Islands: Varanleg verðmætasköpun og hagsæld! Í Auður Hermannsdóttir, Margrét Sigrún Sigurðardóttir og Snjólfur Ólafsson (ritstj.), Vorráðstefna Viðskiptafræðistofnunar Háskóla Íslands (bls. 77-88). Reykjavík: Viðskiptafræðistofnun Háskóla Î́slands.

Harper, G., Cotton, C., og Benefield, Z. (2013). Nashville Music Industry: Impact, Contribution and Cluster Analysis. Nashville Chamber of Commerce. http://www. nashville chamber. com/docs/default-source/researchcenter-studies/nashville-music-industry-study. pdf.

Heur, v. B. (2008). The Clustering of Creative Networks: Between Myth and Reality. Urban Study Journal, 46 (8), 1531-1552.

Höfundalög nr. 73/1972.

Ingstrup, M.B. og Damgaard, T. (2013). Cluster facilitation from a cluster live cycle perspective. European Planning Studies, 21 (4), 556-574.

Jansson, J. og Power, D. (2010). Fashioning a global city: global city brand channels in the fashion and design industries, Regional Studies, 44 (7), 889-904. 
Jóhann Ágúst Jóhannsson (2014). Égámig sjálf: stærri markaður, meirivinna og minni tekjurítónlistariðnaði nútímans. (MA-ritgerð) Háskólinn á Bifröst. Sótt 15. nóvember 2017 af https://skemman.is/bitstream/1946/20567/5/Johann_Agust_Johannsson_MA.pdf

Ketels, C.H.M. (2003). The development of the cluster concept - present experience and further developments. Paper Presented at the NRW Conference on Clusters, Duisburg, Germany, 5. December.

Ketels, C.H.M. (2009). Clusters, cluster policy, and Swedish competitiveness in the global economy. Globalisation Council.

Ketels, C.H.M. (2013). Recent research on competitiveness and clusters: what are the implications for regional policy. Cambridge Journal of Regions, Economy and Society, 6 (2), 269-284.

Ketels, C.H.M. and Sölvell, Ö. (2006). Clusters in the EU-10 new member countries, European Commission - DG Industry, Brussels.

Ketels, C.H.M. og Memedovic, O. (2008). From clusters to cluster-based economic development, Int. J. Technological Learning, Innovation and Development, 1 (3), 375-392.

Kristján Már Gunnarsson (2016). Að slá í gegn. Græða íslenskar hljómsveitir á pví að segjast vera frá Íslandi? (MS-ritgerð) Háskóli Íslands, Viðskiptafræðideild. Sótt 15. nóvember 2017 af https://skemman.is/bitstream/1946/ 24086/3/A\%C3\%B0\%2bsl\%C3\%A1\%2b\%C3\%AD\%2bgegn.pdf

Lindqvist, G., Ketels, C.H.M., og Sölvell, Ö. (2012). The Cluster Initiative Greenbook 2.0. Stockholm. Ivory Towers Publishers.

Lazzeretti, L. (2008). The cultural districtualisation model. Í P. Cooke og L. Lazzeretti (ritstj.), Creative Cities, Cultural Clusters and Local Development (93-120). Cheltenham: Edward Elgar.

Lazzeretti, L., Sedita, S. R., og Caloffi, A. (2014). Founders and disseminators of cluster research. Journal of Economic Geography, 14 (1), 21-43.

Lög um fjárhagslegan stuðning við tónlistarskóla nr. 75/1985.

Lög um listamannalaun nr. 57/2009.

Lög um tónlistarsjóð nr. 76/2004.

Margrét Sigrún Sigurðardóttir og Tómas Young (2011). Kortlagning á hagrænum áhrifum skapandi greina. Reykjavík: Samráđsvettvangur skapandi greina, Íslandsstofa, Mennta- og menningarmálaráðuneyti, Efnahagsog viðskiptaráðuneyti, Iðnaðarráđuneyti, Fjármálaráðuneyti og Utanríkisráðuneyti.

Markusen, A. (1996). Sticky places in slippery space: a typology of industrial districts. Economic Geography, 72 (3), 293-313.

Martin, R. Florida, R. Pogue, M., og Mellander, C. (2015). Creativity, Clusters and the Competitive Advantage of Cities. Working Paper, Rotman School of Management, University of Toronto.

Martin, R., og Sunley, P. (2003). Deconstructing clusters: chaotic concept or policy panacea? Journal of Economic Geography, 3 (1), 5-35.

Marshall, A. (1920). Principles of economics. London: MacMillan.

Mennta- og menningarmálaráðuneytið (2000). Aðalnámskrá tónlistarskóla. Reykjavík: Menntamálaráðuneytið

Mennta- og menningarmálaráðuneytið (2013). Menningarstefna. Reykjavík: Mennta- og Menningarmálaráðuneyti.

MíT (e.d). Sótt 6. apríl 2017 af www. Menton.is

Porter, M. E. (1990). The Competitive Advantage of Nations. New York: The Free Press.

Porter, M. E. (1998). Clusters and the New Economics of Competition. Í M. E. Porter (ritstj.), On Competition (197-287). Boston: Harvard Business School Publishing.

Porter, M. E. (2000). Location, Competition, and Economic Development: Local Clusters in a Global Economy. Economic Development Quarterly, 14 (1), 15-34.

Porter, M. E. (2003). The economic performance of regions. Regional Studies, 37, 549-578.

Porter, M. E. (2008). On Competition (2. ed). Boston: Harvard Business School Publishing.

Power, D. og Jansson, J. (2006). Creative Directions - a Nordic framework for supporting the creative industries. Ósló: Norræna nýsköpunarmiðstöðin.

Reykjavíkurborg (2014). Greining á fjárhagsvanda tónlistarskóla í Reykjavík. Reykjavík: Reykjavíkurborg.

Robson C. (1993). Real World Research. A Resource for Social Scientists and Practicioner-Researchers. Oxford. Blackwell Publishers.

Rosenfeld, S. A. (1997). Bringing Business Clusters into the Mainstream of Economic Developement. European Planning Studies, 5 (1), 3-23.

Runólfur Smári Steinpórsson (2016a). Klasakort, verkfæri við kortlagningu klasa. Klasar, ársrit um klasa. 2 (1), $18-28$

Runólfur Smári Steinpórsson (2016b). Klasaframtök og klasamiðstöðvar sem aflvakar innan klasa. Klasar, ársrit um klasa, 2 (1), 34-42.

Smith, H. L. (2007). Universities, innovation, and territorial development: A review of the evidence. Environment and Planning. C, Government \& Policy, 25 (1), 98-114.

Stiles, C. H. (1992). The Influence of Secondary Production on Industry Definition in the Extended Vertical Market Model. Strategic Management Journal, 13 (3), 171-187.

STS. (e.d). sótt 6. apríl 2017 af http://www.tonlistarskolarnir.is/is/. 
Sölvell, Ö. (2008). Clusters: Balancing Evolutionary and Constructive Forces. Stokkhólmur, Ivory Tower Publishers.

Sölvell, Ö., Lindqvist, G., Ketels, C. (2003). The Cluster Initiative Greenbook. TCI Global Conference. Stokkhólmur: TCI.

Sölvell, Ö., Williams, M. (2013). Building the Cluster Commons - An Evaluation of 12 Cluster Organizations in Sweden 2005 - 2012. Stockholm. Ivory Tower Publishers.

Throsby, D. (2003). Determing the value of Cultural Goods: How much (or little) does contingent valuation tell us? Journal of Cultural Economics 27, 275-281.

Tómas Young (2013). Tónlistarhátíđir á Íslandi. Reykjavík: Ferðamálastofa.

Tómas Young (2008). Íslensk tónlist sem landkynning. (BA-ritgerð) Háskóli Íslands, Raunvísindadeild. Sótt 15. nóvember 2017 af https://skemman.is/bitstream/1946/6392/1/BSc\%20-\%20\%C3\%8Dslensk\%20 t\%C3\%B3nlist \%20sem\%20landkynning\%20-\%20T\%C3\%B3mas\%20Viktor\%20Young.pdf

Towse, R. (2010). A textbook of Cultural Economics. New York and Cambridge: Cambridge University Press.

ÚTÓN, Um ÚTÓN, sótt 6. apríl 2017 af Uton.is, http://www.uton.is/um-uton

Yin, R. K. (2003). Case Study Research: Design and Methods (3. útg.). Newbury Park: Sage Publication.

Vang, J. (2007). The spatial organization of the news industry: questioning assumptions about knowledge externalities for clustering of creative industries. Innovation: Management, Policy and Practice 9 (1), 14-27.

Wolfe, D. A. (2005). The Role of Universities in Regional Development and Cluster Formation í G. A. Jones, P. L. McCarney, M. L. Skolnik (ritstj.). Creating Knowledge, Strengthening Nations: The Changing Role of Higher Education, (167-194). University of Toronto Press.

Wolman, H., og Hincapie, D. (2015). Clusters and Cluster-Based Development Policy. Economic Development Quarterly 29 (2), 135-149.

Ævar R. Hafpórsson (2013). Hagræn áhrif Iceland Airwaves 2012. Margföldunaráhrif. (B.S.-ritgerð) Háskóli Íslands, Hagfræðideild. Sótt 15. nóvember 2017 af https:/skemman.is/bitstream/1946/16532/1/Lokaskil\%20 \%C3\%A1\%20BA\%20verkefni.pdf 
